\title{
CHILDHOOD OBESITY AND ITS \\ IMPACT ON BLOOD PRESSURE
}

\author{
PhD THESIS \\ Andrea Emese Jakab, MD \\ Consultant: Csaba Bereczki, MD, PhD \\ Clinical Medical Sciences Doctoral School
}

Program Director: Prof. Lajos Kemény, MD, PhD, DSA

SZEGED

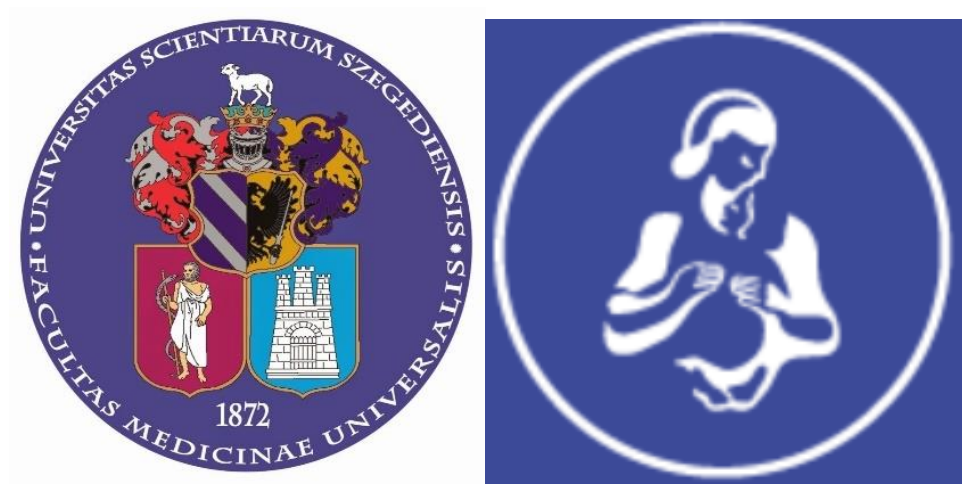

Department of Pediatrics and Pediatric Health Center, Faculty of Medicine

Albert Szent-Györgyi Health Center

University of Szeged 


\section{PUBLICATIONS DIRECTLY RELATED TO SUBJECT OF THE THESIS}

I. Andrea Emese Jakab, Miklós Illyés, Attila Cziráki, Erzsébet Valéria Hidvégi, Csaba

Bereczki. Prevalence of Overweight and Obesity in Hungarian Children and Adolescents. Annals of Nutrition and Metabolism. 2018; 72:259-264. (IF: 2,424)

II. Andrea Emese Jakab, Erzsébet Valéria Hidvégi, Miklós Illyés, Attila Cziráki, Tibor Kalmár, Zoltán Maróti, Csaba Bereczki. Prevalence of Hypertension in Overweight and Obese Hungarian Children and Adolescents. Orvosi Hetilap. 2020; 161:151-160. (IF: 0,564)

III. Andrea Emese Jakab, Miklós Illyés, Attila Cziráki, Csaba Bereczki, Erzsébet Valéria Hidvégi. Prevalence of Overweight and Obesity in a Population Aged between 3-18 Years in Szolnok. Gyermekgyógyászat. 2018; 68:107-112.

\section{ABSTRACTS DIRECTLY RELATED TO SUBJECT OF THE THESIS}

I. Erzsébet Valéria Hidvégi, Andrea Emese Jakab, Miklós Illyés, Attila Cziráki. Childhood obesity: Does it Have any Effect on Young Arteries? ARTERY18, 18-20 October 2018, Guimarães, Portugal. Artery Research. 2018; 24:75.

II. Andrea Emese Jakab, Erzsébet Valéria Hidvégi, Miklós Illyés, Attila Cziráki, Csaba Bereczki. Non-Invasive Assessment of Arterial Function in Overweight and Obese Children and Adolescents. 51 $1^{\text {st }}$ Annual Meeting of the Association for European Paediatric and Congenital Cardiology. 29 March - 01 April 2017, Lyon, France. Cardiology in The Young. 2017; 27:Suppl.2 p.12.

III. Erzsébet Valéria Hidvégi, Andrea Emese Jakab, Miklós Illyés, Attila Cziráki, Csaba Bereczki. Non-invasive Assessment of Arterial Function Parameters in Overweight and Obese Children and Adolescents. Annual Meeting of the Hungarian Society of Cardiology. 05-07 May 2016, Balatonfüred, Hungary. Cardiologia Hungarica 2016; 46:53-54.

IV. Andrea Emese Jakab, Erzsébet Valéria Hidvégi, Miklós Illyés, Attila Cziráki, Csaba Bereczki. Prevalence of Overweight and Obesity in a Population Aged between 3-18 Years in Szolnok. Annual Meeting of the Hungarian Society of Peadiatrics. 22-24 September 2016, Szeged, Hungary. Gyermekgyógyászat. 2016; 67:298. 
PUBLICATION ON OTHER TOPIC:

I. Anette Wecker-Gussmann, Doris Ehringer-Schetitska, Vesna Herceg-Cavrak, Erzsébet Valéria Hidvégi, Andrea Emese Jakab, Andreas Petropoulos, Ero Jokinen, Peter Fritsch, Renate Oberhoffer. Prevention of Delayed Diagnosis in Congenital Heart Disease. Cardiology in the Young. 2019; 29:730-731.

ABSTRACTS ON OTHER TOPIC:

I. Erzsébet Valéria Hidvégi, Andrea Emese Jakab, Attila Cziráki, Miklós Illyés. Updated and Revised Reference Values of Aortic Pulse Wave Velocity in Children and Adolescents Aged 3-18 Years. 53rd Annual Meeting of the Association for European Paediatric and Congenital Cardiology (AEPC) 15-18 May 2019, Seville, Spain. Cardiology in the Young. 2019; 29:Suppl.1 p.143.

II. Andrea Emese Jakab, Robert Dalla Pozza, Doris Ehringer-Schetitska, Peter Fritsch, Renate Oberhoffer, Andreas Petropoulos. Assessment of Pulse Oximetry Screening Trends in AEPC. 52nd Annual Meeting of the Association for European Paediatric and Congenital Cardiology (AEPC). 9-12 May 2018, Athens, Greece. Cardiology in the Young. 2018; 28:Suppl.1 p.175.

III. Andreas Petropoulos, Peter Fritsch, Doris Ehringer-Schetitska, Vesna HercegCavrak, Andrea Emese Jakab, Erzsébet Valéria Hidvégi, Renate Oberhoffer. Adapting Pulse Oximetry Measurements for Early Detection of Critical Congenital Heart Disease in Early Neonatal Period. 50th Annual Meeting of the Association for European Paediatric and Congenital Cardiology (AEPC). 1-4 June 2016, Rome, Italy. Cardiology in the Young. 2016; 26:Suppl.2 p.12. 


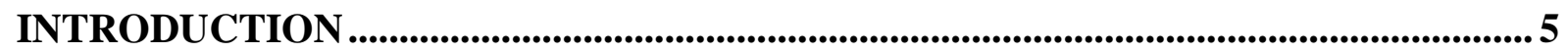

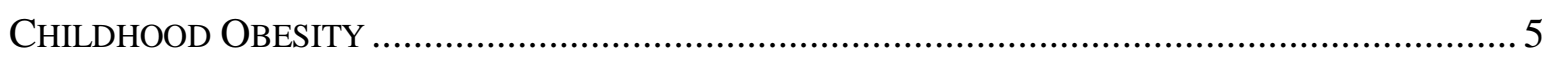

Prevalence of Overweight and Obesity in the World.......................................................... 5

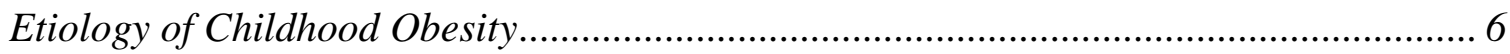

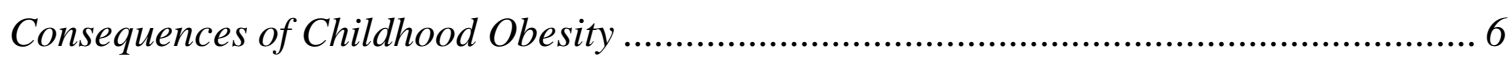

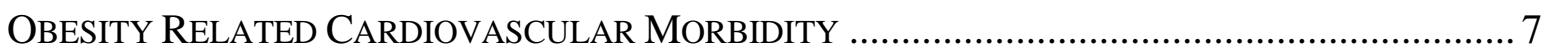

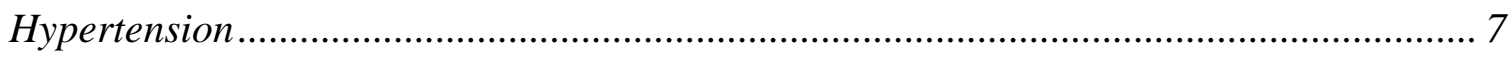

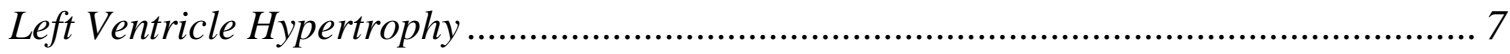

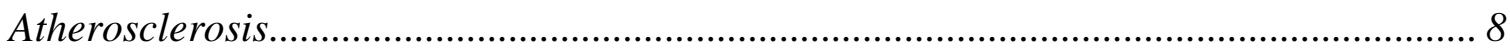

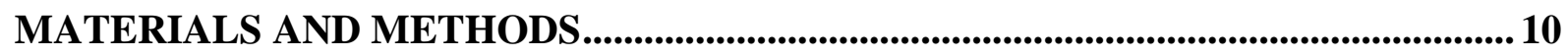

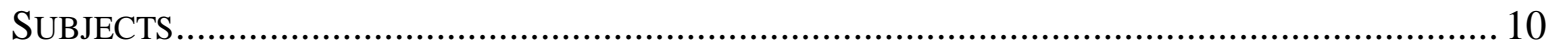

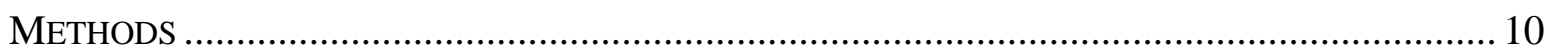

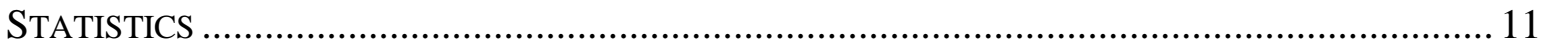

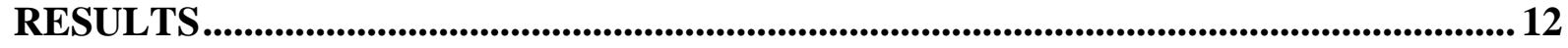

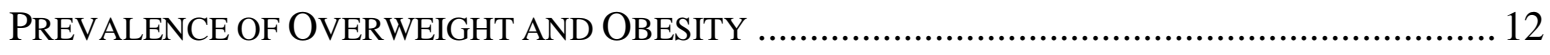

PREVALENCE OF OVERWEIGHT AND OBESITY ASSOCIATED HYPERTENSION ......................... 14

DISCUSSION ...................................................................................................................................... 24

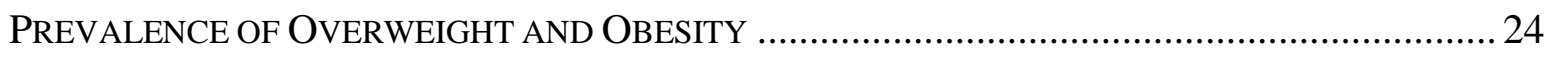

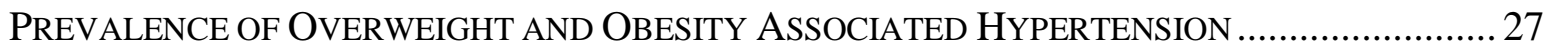

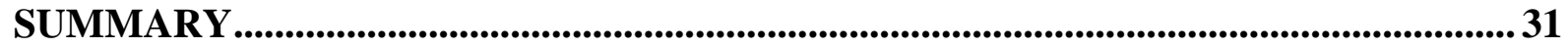

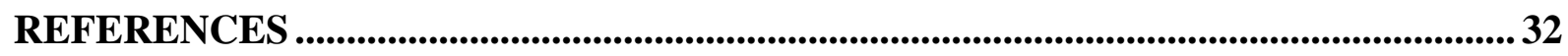

ACKNOWLEDGEMENTS .................................................................................................................. 46 


\section{Abbreviations}

ABPM: ambulatory blood pressure monitor

BMI: body mass index

BP: blood pressure

CI: confidence interval

DBP: diastolic blood pressure

DI: diurnal index

E BP: elevated blood pressure

ECG: electrocardiography

GP: general practitioner

H BP: high blood pressure

HR: heart rate

HTN: hypertension

IOTF: International Obesity Task Force

N BP: normal blood pressure

$\mathrm{N}$ : normal weighted

O: obese

OR: odds ratio

OW: overweight

SBP: systolic blood pressure

SD: standard deviation

SP: school physician

TEE: total energy expenditure

WHO: World Health Organisation 


\section{Introduction}

\section{Childhood Obesity}

According to the World Health Organisation (WHO), overweight and obesity are defined as abnormal or excessive fat accumulation that presents a risk to health. A crude population measure of obesity is the body mass index (BMI), a person's weight (in kilograms) divided by the square of his or her height (in metres). An adult person with a BMI of 25 to 29.99 is generally considered overweight, with a BMI equal to or more than 30 is considered obese. Obese class I means that BMI is between 30.00-34.99, in obese class II the BMI is between 35.00-39.99 and finally, obese class III are patients with BMI equal to or above 40.00. For children under 5 years of age: overweight is weight-for-height greater than 2 standard deviations (SD) above WHO Child Growth Standards median; and obesity is weight-for-height greater than 3 SD above the WHO Child Growth Standards median. Overweight and obesity are defined as follows for children aged between 5-19 years: overweight is BMI-for-age greater than $1 \mathrm{SD}$ above the WHO Growth Reference median; and obesity is greater than 2 SD above the WHO Growth Reference median [1]. World Obesity / Policy \& Prevention (formerly International Obesity Task Force or IOTF) has adapted adult BMI cut-off values (16, 17, 18.5, 25, 30 and 35 $\mathrm{kg} / \mathrm{m}^{2}$ ) to child centiles [2], which is easy to derive and they can be expressed as BMI centiles. It is more useful in paediatric population, because WHO standards (due to its construction method) are relatively low in young patients and high in older subjects [2].

\section{Prevalence of Overweight and Obesity in the World}

The increasing number of overweight and obese children and adolescents has become a serious and alarming phenomenon worldwide. Between 1980 and 2013, the prevalence of overweight and obesity increased from $10 \%$ to $12.7 \%$ in the population aged $2-19$. This rate is even worse in the industrialised countries: during the period analysed, the prevalence increased from $16.9 \%$ to $23.8 \%$ in boys, and from $16.2 \%$ to $22 \%$ in girls [3]. Between 1975 and 2016, the mean BMI raised in boys, as well in girls worldwide. The pace of the increment is shocking, in cc. 40 years the prevalence increased from 10 million to more than 70 million in boys in the Central and Eastern Europe region, and from 10 million to 50 million in girls in the same region [4]. The epidemic of overweight and obesity has intensified the speed of research, in order to identify the possible reasons and the harmful consequences of this conditions not only in childhood, but in adults as well. 


\section{Etiology of Childhood Obesity}

Obesity is subdivided in two subgroups: exogenous and endogenous [5]. Endogenous may be caused by different endocrine malfunctions, genetic or syndromic causes; whereas exogenous could be resulted from the imbalance between energy intake and expenditure, or from medications (e.g., glucocorticoids, tricyclic antidepressants), or even from impaired metabolic programming [5]. Considering the fact, that the target population of this research were children with exogenous obesity, the following part of the thesis will give a summary about this subgroup.

Although researchers have took efforts to explore the genetic factors and molecular background of the individual susceptibility to obesity, these findings cannot explain the obesity epidemic entirely. Genes of the human body have not changed substantially during the past decades [6]. Promotions of the obesogenic behaviour is responsible for obesity nowadays. Gaining weight in this increasing obesogenic environment is very easy for children, while it requires sustained efforts remaining fit and healthy [6]. Contributing environmental factors for increased BMI could be divided into three subgroups. Firstly, individual behaviours such as unhealthy dietary habits including the consumption of energy dense food, large portion sizes and excessive snacking [7], reduced sleep time resulting from increased screen time (television, mobile phone or tablets) [8], lack of regular physical activity or sedentary lifestyle [9]. Secondly, to microenvironmental factors belong family (parenting styles and different patterns of diet and physical activity, smoking and alcohol consumption influence the child's choices) [10,11] school (lack of healthy lifestyle education, sport facilities, unhealthy lunches) [12,13] and neighbourhood (playgrounds, closeness of healthy food groceries) [14-16]. Thirdly, macro-environmental factors are food industry - which have an impact on the risk of obesity with the production, marketing and advertising of high fat and sugar containing foods - and government, which should provide a healthy environment for children and should follow a strict, restrictive policy aiming the reduction of the availability of unhealthy snacks [7,17]. Considering the highlights of the literature, we may conclude to the possible solution: we must "cure" environment first, to combat the alarming increase of obesity [6].

\section{Consequences of Childhood Obesity}

Medical researchers have long recognized that being overweight or obese carries many serious health risks for adults [18]. The question rises, whether children face the same range of risks as adults or they form an exceptional group. Several conditions, thought to be only applicable in adulthood are now being represented in youth, moreover, they are becoming more frequent than 
before. Children are more vulnerable to obesity-related diseases, because their bodies are in a growing and developing phase. Overweight and/or obesity are not merely an aesthetical issue for the individuals, but consequences of this condition having an adverse, either immediate or long-term effect on their health. These obese children are more prone to have early atherosclerosis [19], hypertension [20] or diabetes mellitus [21] as adults. Moreover, this condition may also result in insulin resistance [22], metabolic syndrome [23], dyslipidaemia [24], it may contribute to obstructive sleep apnoea [25]; furthermore, non-alcoholic fatty liver disease [26], gastroesophageal reflux [27], tibia vara (Blount disease) [28] may also be developed, or even psychic condition may be affected (depression) [29].

\section{Obesity Related Cardiovascular Morbidity}

The cardiovascular system consists of a dynamic series of conduits, which are vulnerable to many illnesses that may result in myocardial infarction - in the case of heart arteries - or in stroke - in the case of cerebral arteries. These processes make the heart also assailable to thickening of the heart muscles resulting in diminished function [30].

\section{Hypertension}

Overweight and obesity are main contributing factors to develop hypertension not only in adulthood but in childhood, as well [31]. There are factors simultaneously attenuating and stimulating the development of high blood pressure in overweight adolescents. Stimulating factors may be older age, low birth weight or pubertal status, while attenuating factors are high cardiorespiratory fitness or Central European ethnicity [32]. Recent study has found that the odds for hypertension are 1.5 times higher in children with overweight, while in obese patients these odds are $1.8-3.5-5.7$ times higher for primary hypertension compared to their normal weight pupils [33]. Consequently, the higher is the frequency of children with overweight or obesity, the higher is the portion of children suffering from hypertension [34].

\section{Left Ventricle Hypertrophy}

Uncontrolled high blood pressure - resulting in an increased load - forces the heart to provide increased effort to pump blood via the aorta into the rest of the human body. This process may lead to thickening of the main pumping chamber, to left ventricle hypertrophy. Similarly to hypertension, left ventricle hypertrophy also shows a strong correlation with increased BMI in childhood [35]. Researchers have found, that the reason for this could be that the development of the heart follows the development of the body composition [36]. This suggests that in a body 
with excessive amount of fat tissue, the left heart chamber should thicken itself ultimately. Subsequently this hypertrophy could moderately increase the risk for CV morbidity [37].

\section{Atherosclerosis}

Hardening of the arteries is a progressive condition, called atherosclerosis, which starts with a fatty streak on the inner layer of the vessel (endothelium), and it continues with a fibrous plaque, finally it may be followed by a rupture and thrombosis of the plaque leading to a blockage in the blood flow. The Pathobiological Determinants of Atherosclerosis in Youth (PDAY) study [38] and the Bogalusa study [39] helped to clarify the prevalence of atherosclerosis in adolescents and in young adults and the connection between obesity and atherosclerosis. In the PDAY study autopsy was used to identify lesions on the surfaces of the aorta and left coronary artery in subjects who died of accidents, murders or suicides, hypothesized that they were "healthy" subjects, not suffering from any disease at the time of the death. This working group described, that atherosclerosis begins already in youth, and the prevalence of fatty streaks and clinically significant lesions raises suddenly in the 15- to 34-year age span. Surprisingly, the prevalence of fatty streaks was $100 \%$ in white and black subjects in each age group. In the age group $15-19$ years a total of $13.1 \%$ white men and $6.8 \%$ of white women suffered from fibrous plaque in the abdominal aorta, and $3.3 \%$ of white men and $1.5 \%$ of white women suffered from fibrous plaque in the thoracic aorta [38]. Bogalusa study identified with the help of antemortem analysis the possible link between elevated BMI and early atherosclerosis [39]. These results demonstrate the presence of atherosclerosis even in children at very young age and the harmfulness of increased BMI on the cardiovascular system. Health professionals should bear in mind that atherosclerosis starts decades earlier before having clinical manifestation, already in childhood, moreover overweight and obesity are significantly related to the atherosclerotic lesions.

Considering the detailed facts above, it is strongly suggested to perform proper measurements regularly, in order to monitor the possible effects of several prevention projects and trends in the investigated population regarding body weight, furthermore overweight and obesity associated hypertension. This thesis was designed to assess these changes in Hungarian children and adolescents. 


\section{Aims}

Goals of this thesis are the followings:

1. To determine the prevalence of overweight and obesity in a healthy population aged 3-18 in Szolnok city and the surrounding area.

A. To discover if there is any difference in age and sex distribution regarding the prevalence of overweight and obesity.

B. To observe if there have been any changes in the prevalence and in the trends of overweight and obesity from the data measured previously in Hungary.

2. To assess the prevalence of overweight and obesity associated hypertension in children aged 3-18 in Szolnok city and the surrounding area.

A. To observe if there is any difference in age and sex distribution in this population.

B. To establish if there is any relationship between BMI categories and frequency of hypertension.

C. To compare our data with international findings on overweight and obesity associated hypertension. 


\section{Materials and Methods}

\section{Subjects}

In order to assess the prevalence of overweight $(\mathrm{OW})$, obese $(\mathrm{O})$ and normal weighted $(\mathrm{N})$ children in the first analysis 6.824 subjects (3.673 boys) aged 3-18 years were recruited from elementary, primary and high schools in Szolnok town (Hungary) between 2012 and 2016. For the second study 8.624 subjects ( 4.719 boys) aged 3-18 years were enrolled between 2005 and 2018 to estimate the prevalence of hypertension in subjects with elevated BMI. All the subjects were Caucasian without any chronic diseases, and they were not on any regular medications. Informed consent for the measurements was asked for from the parents of the subjects. The protocol was reviewed and approved by the local Institutional Ethics Committee of the University of Pécs, Pécs, Hungary.

\section{Methods}

Height and weight measurements were performed in accordance with the Hungarian professional rules [40], using a Kern MGB 150K 100 type personal scale and a MSF 200 type mechanical height rod (Kern \& SOHN GmbH, Germany). The subjects were categorised by their body mass index (BMI) into normal weight, overweight and obese groups regarding their age and sex, as well [2].

Blood pressure was taken with an occlusive-oscillometric device (Arteriograpgh, Tensiomed Ltd., Hungary), which has been validated both invasively and non-invasively [41,42]. In patients, where the systolic (SBP) and/or diastolic blood pressure (DBP) were found to be equal or over $90^{\text {th }}$ percentile according to age, height and sex blood pressure (BP) measurement was repeated two times with 10 minutes pause in between. If these results were found to be elevated $\left(95^{\text {th }}>\mathrm{BP} \geq 90^{\text {th }}\right)$ or hypertension was suspected $\left(\mathrm{BP} \geq 95^{\text {th }}\right)$ [43-46], it was suggested to perform regular check-ups by the school physicians or by the general practitioner. If blood pressure was still found to be over the normal percentile, the subject was referred to a paediatric cardiologist for a detailed examination. Firstly, to exclude secondary hypertension abdominal ultrasound was performed (especially focusing on the kidneys and the adrenal glands), followed by a blood test (including bloodwork, fasting glucose, ions, renal- and liver functions, lipids, thyroid stimulating hormone). The examination composed of 12-leads ECG, echocardiography (also to rule out coarctation aortae and to assess left ventricular hypertrophy), and finally 24-hours ambulatory blood pressure monitoring (ABPM) (CardioTens 01, CardioTens 02, Meditech Ltd, Budapest, Hungary). For the ABPM four different sizes of cuff were used according to the arm 
circumference of the non-dominant arm $[43,46]$. Relevant guidelines were applied to analyse the ABPM results $[47,48]$. The diagnosis of hypertension was set up if the average SBP and/or DBP was equal or above the $95^{\text {th }}$ percentile according to age, sex and height and secondary hypertension was excluded. "Elevated BP" subgroup $\left(90^{\text {th }} \leq \mathrm{BP}<95^{\text {th }}\right)$ was created for the appropriate result-comparison with the relevant literature.

\section{Statistics}

Data are reported as mean and SD for continuous data. For data comparison, Student's $t$-test was carried out after checking that the assumption of normality was met. Significance levels were set at the 5\% level using the student t-test. To ensure data comparison between sexes, chisquared test was carried out. Fisher's exact test was applied to compare the prevalence with the previous Hungarian data. Statistical analysis was performed with the SPSS 23.0 statistical package (SPSS Inc., Chicago, Illinois, USA). 


\section{Results}

\section{Prevalence of Overweight and Obesity}

Table 1 contains the results of the prevalence of overweight and obesity. The prevalence of overweight was $13.4 \%(n=915)$, and $6.6 \%$ of obesity, which is $20 \%(n=1.363)$ of the studied population aged $3-18$, in total.

Table 1 Prevalence of overweight and obesity

\begin{tabular}{ccccccc} 
& \multicolumn{2}{c}{ boys } & \multicolumn{2}{c}{ girls } & \multicolumn{2}{c}{ total } \\
normal BMI & $\mathrm{n}$ & $\%$ & $\mathrm{n}$ & $\%$ & $\mathrm{n}$ & $\%$ \\
overweight & 2881 & 78.4 & 2580 & 81.9 & 5461 & $\mathbf{8 0 . 0}$ \\
obese & 518 & 14.1 & 397 & 12.6 & 915 & $\mathbf{1 3 . 4}$ \\
overweight + obese & 274 & 7.5 & 174 & 5.5 & 448 & $\mathbf{6 . 6}$ \\
\hline
\end{tabular}

BMI; body mass index

Table 1 demonstrates that the rate of overweight and obesity is higher in case of boys, than in girls, since the total prevalence of overweight and obesity was $21.6 \%(n=792)$ in boys and $18.1 \%(\mathrm{n}=571)$ in girls. This difference was proven by statistical analysis (chi-square test, $\mathrm{p}<0.005)$. In order to ensure more informative data the age and weight distribution of the participants is indicated in percentage in Figure 1 and 2.

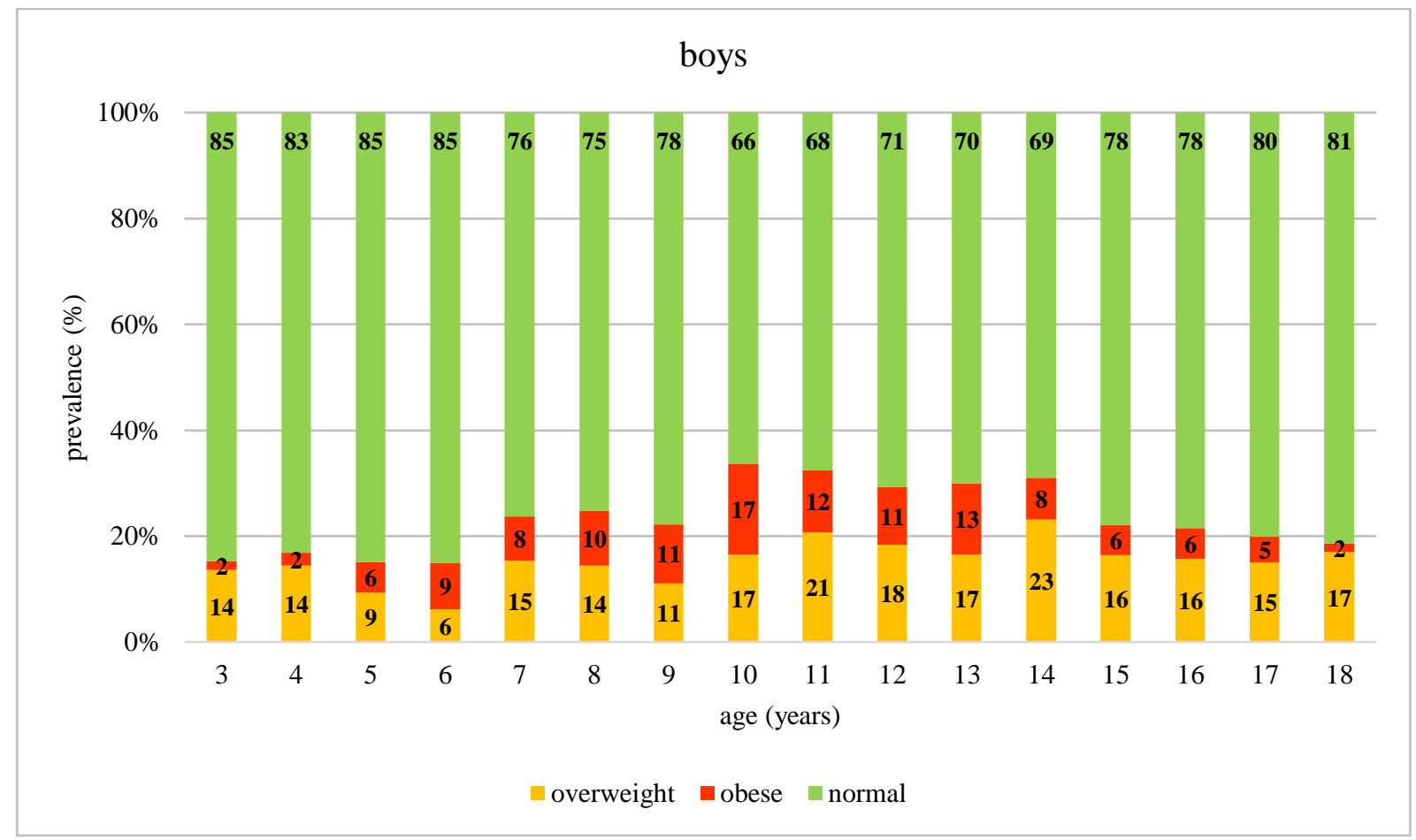

Figure 1 Age-related distribution of BMI categories 


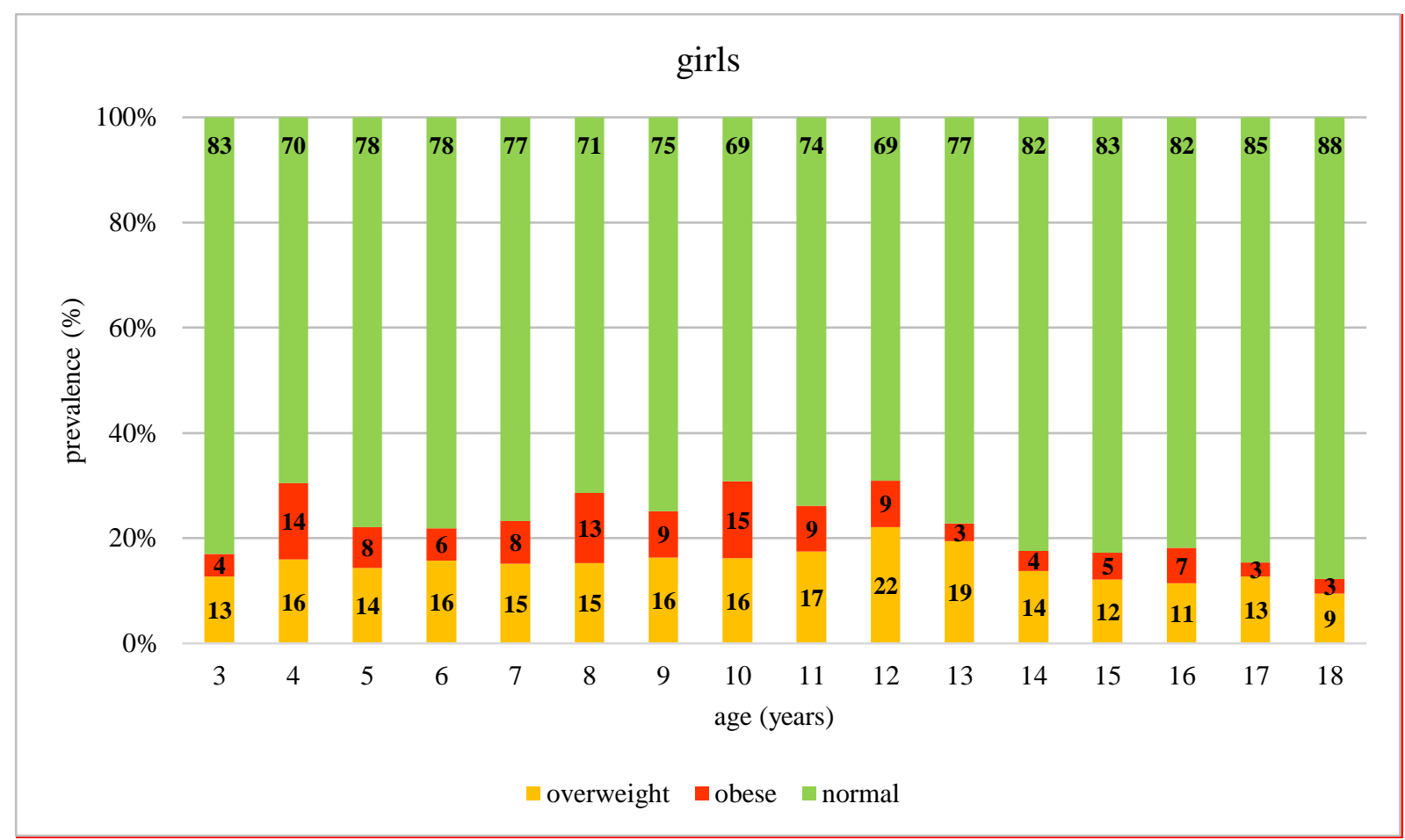

Figure 2 Age-related distribution of BMI categories

The total prevalence of overweight and obesity increases between the ages of 3 to 10 in both sexes, however, this increase is not even. The peaks are observed at the age of 10 in both genders. From 3 to 9 years total frequency of $\mathrm{OW}$ and $\mathrm{O}$ is higher in girls, until it turns from the age of 10. From 10 to 18 this condition is more common in boys. Although these differences are visible on the chart, statistically it is only different at the age of 4 and 14. After puberty, there is a moderate decreasing trend both in boys and girls; however, the decrease is more significant in girls (Figure 3). 


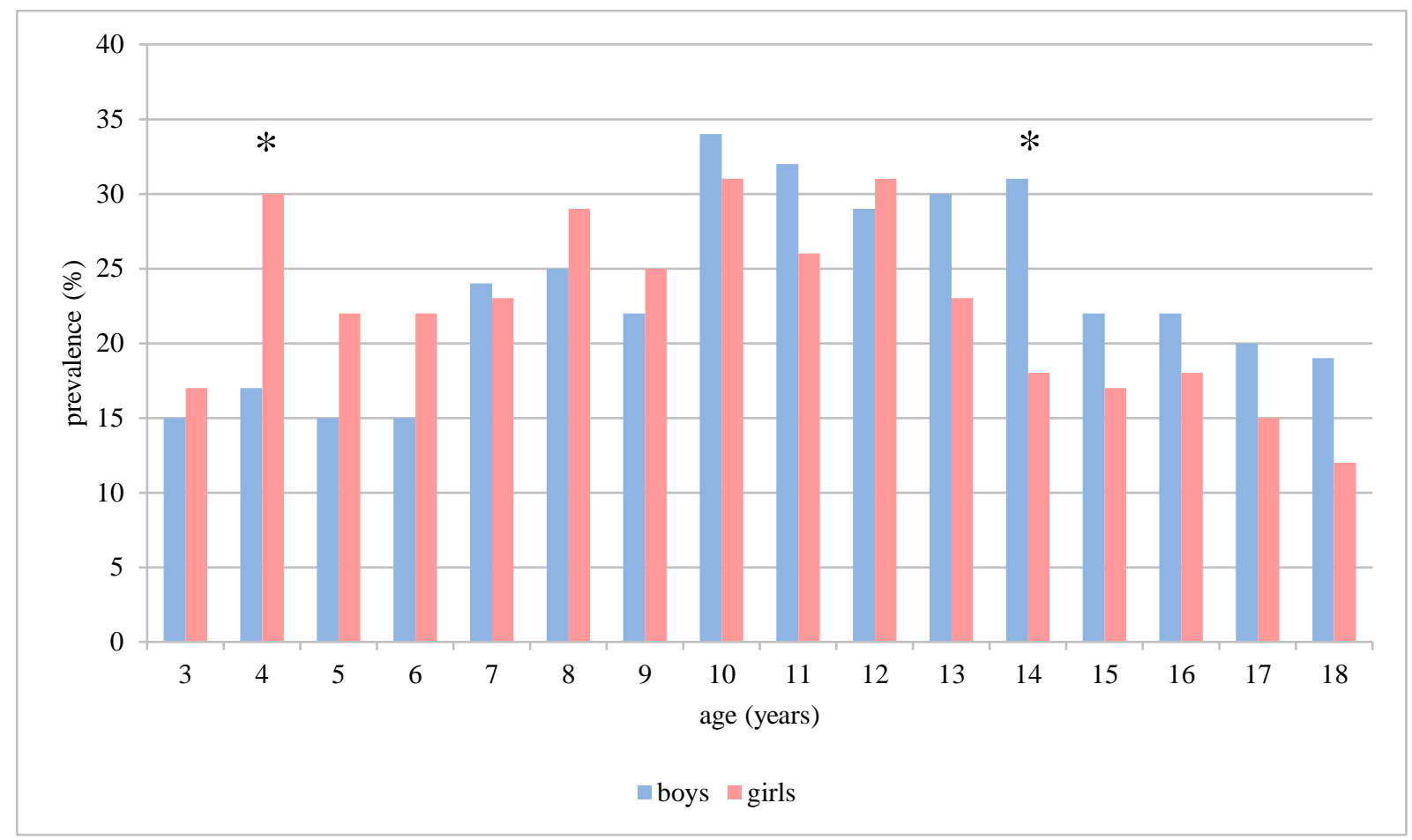

Figure 3 Prevalence of overweight and obesity in different age groups. *; significant difference $(\mathrm{p}<0.05)$

\section{Prevalence of Overweight and Obesity Associated Hypertension}

Characteristics of the N, OW and O subjects are performed in Supplementary Table 1 for boys (1/A), and girls (1/B), including the statistical findings and p-values of each examined parameter. On average, bodyweight, height, BMI, SBP and DBP were shown to have a simultaneous increase with age, however, heart rate (HR) decreases with years in boys and girls, as well. In Supplementary Table 1 there is a clear trend of elevated weight, BMI and SBP in OW and $\mathrm{O}$ children (in both sexes) compared to $\mathrm{N}$ patients, while height and HR did not show any statistical differences.

Supplementary Table 2 summarizes the enrolling method of subjects into this study for normal weighted $(2 \mathrm{~A})$, for overweight $(2 \mathrm{~B})$ and for obese $(2 \mathrm{C})$ boys and girls. The $3^{\text {th }}, 4^{\text {th }}$ and $5^{\text {th }}$ columns of this table show the absolute number of subjects with normal $(\mathrm{N})$, elevated $(\mathrm{E})$ and high $(\mathrm{H}) \mathrm{BP}$ measured on the first meeting. It can be seen that in children with normal weight 3044 boys and 2775 girls had normal, 209 boys and 185 girls elevated, while 305 boys and 169 girls high blood pressure, respectively. After this, in 1.594 (18.5\%) cases regular BP control was suggested, due to suspicion of hypertension (patients with elevated and high BP). Further BP measurements were performed by general practitioners (GP) and/or school physicians (SP). Based on the results of the repeated BP measurements they decided whether the patients should visit a specialist in order to perform a detailed examination targeting hypertension. The $6^{\text {th }}$ 
column contains the number of patients, who were referred to paediatric cardiologist (693 patients, $43.5 \%)$. The $7^{\text {th }}, 8^{\text {th }}$ and $9^{\text {th }}$ columns present the number of patients with normal $(\mathrm{N})$, elevated $(\mathrm{E})$ and high $(\mathrm{H}) \mathrm{BP}$ based on the detailed examination and ABPM performed by specialist. Finally, from the admitted subjects $(n=693)$, elevated BP was found in 177 cases (25.5\%), while hypertension was diagnosed in 353 cases $(50.9 \%)$. Our findings suggest that "white coat effect" was around $23.6 \%$ in this population, considering the fact, that from the admitted patients after the detailed examination $25.5 \%$ had elevated BP and $50.9 \%$ of the patients hypertension.

Figure 4 summarizes total numbers of the patients enrolled to this study according to their sex, age and weight categories (all patients). As this figure shows, most of the majority of the enrolled patients were between the age of 12 and 17 in both sexes. Moreover, on the chart it can be seen the proportions of HTN patients (HTN based on ABPM) among the total population in each age group. The figure shows that the frequency of HTN was higher in every weight category in boys compared to girls. 


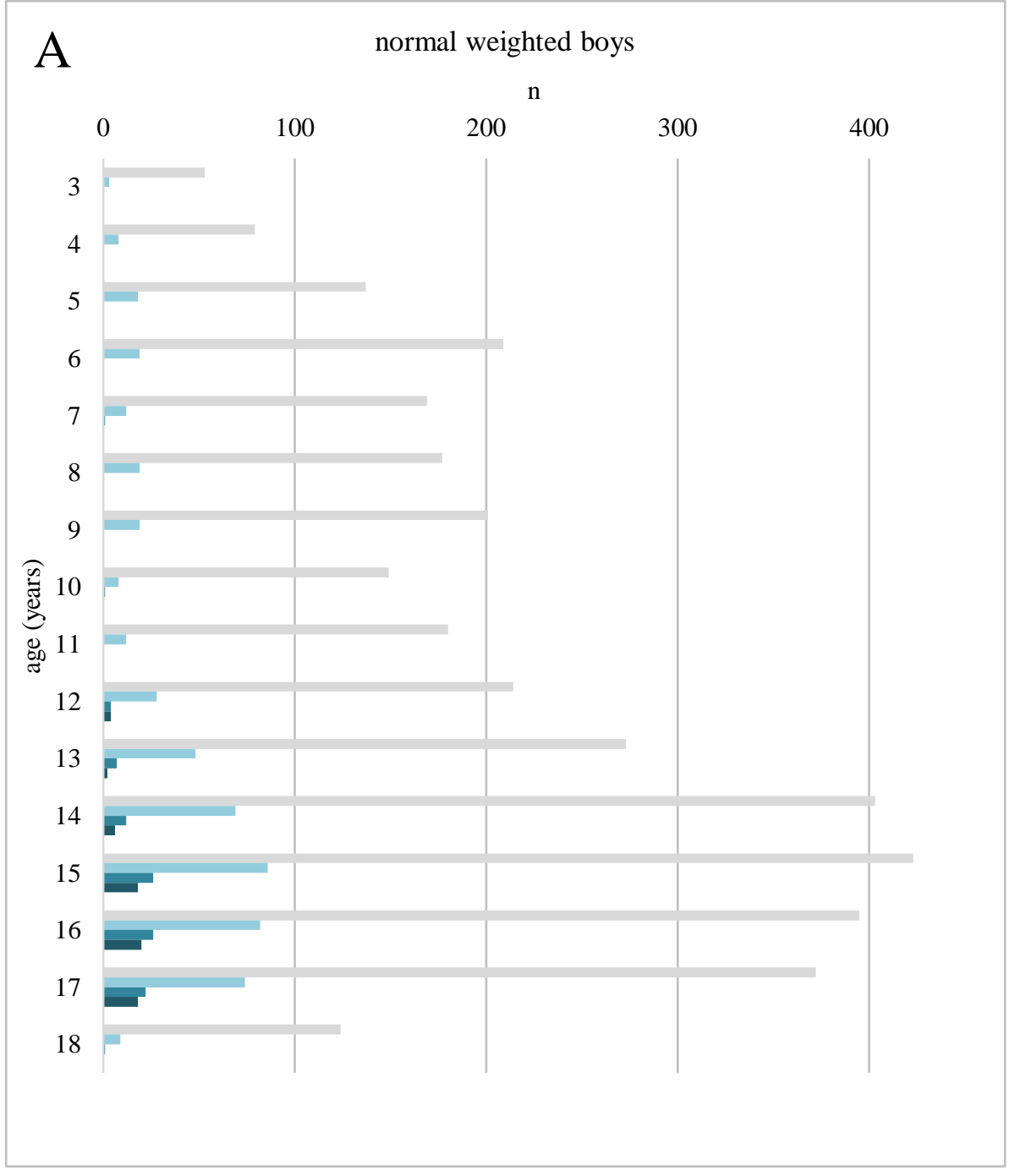

all patients
- elevated / high BP at first measurement

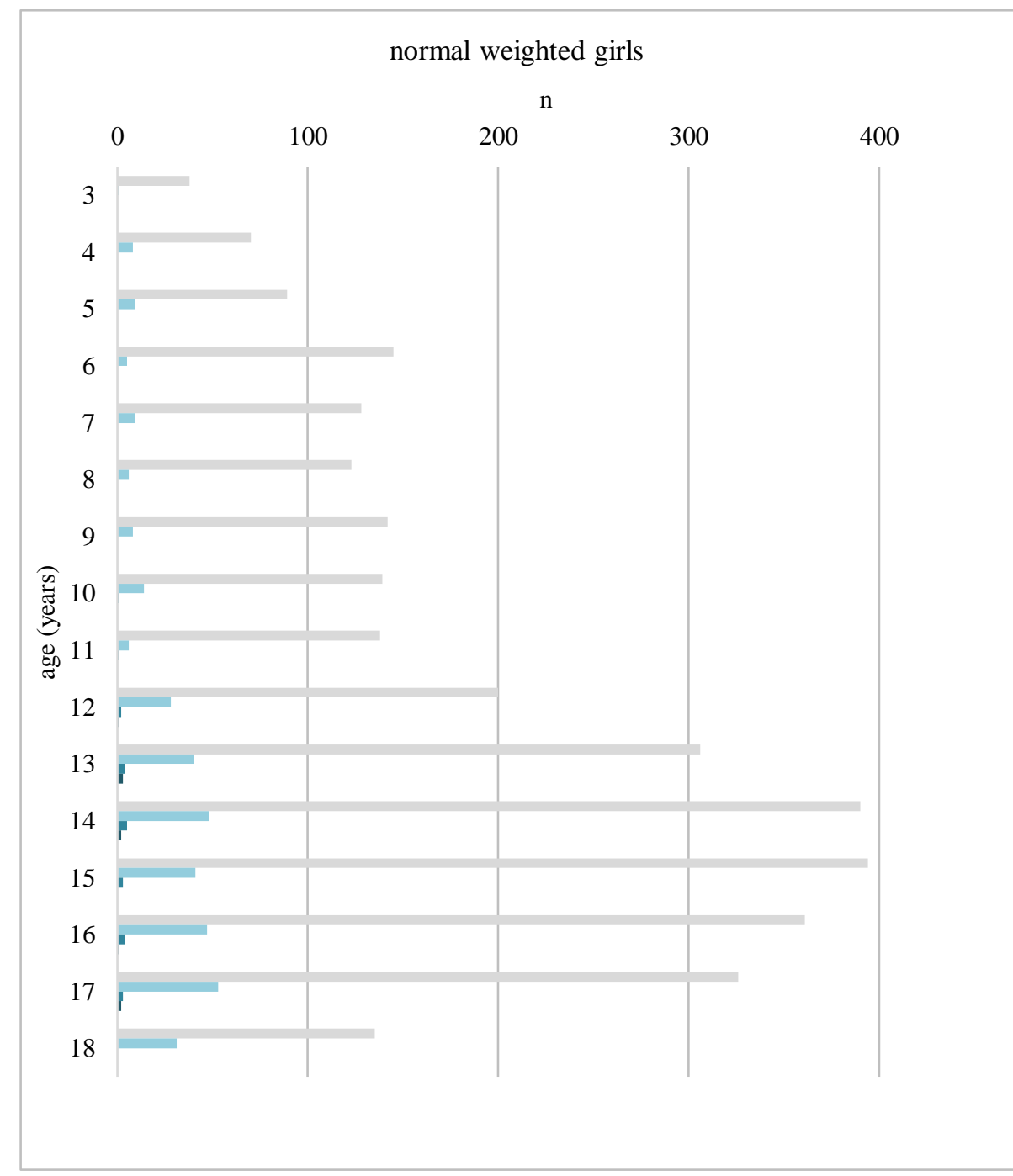

- proposed examination

- elevated / high BP based on ABPM 


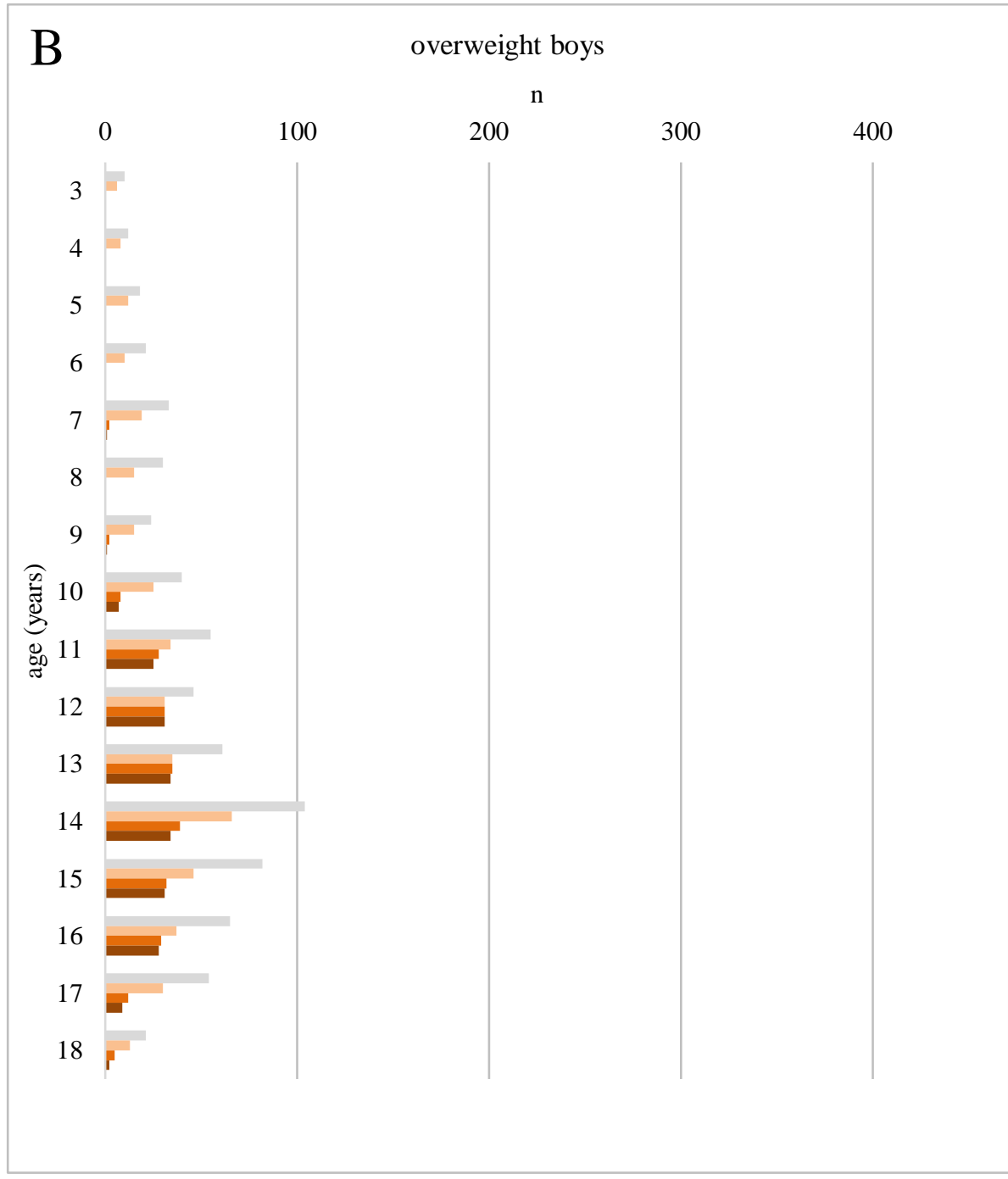

all patients

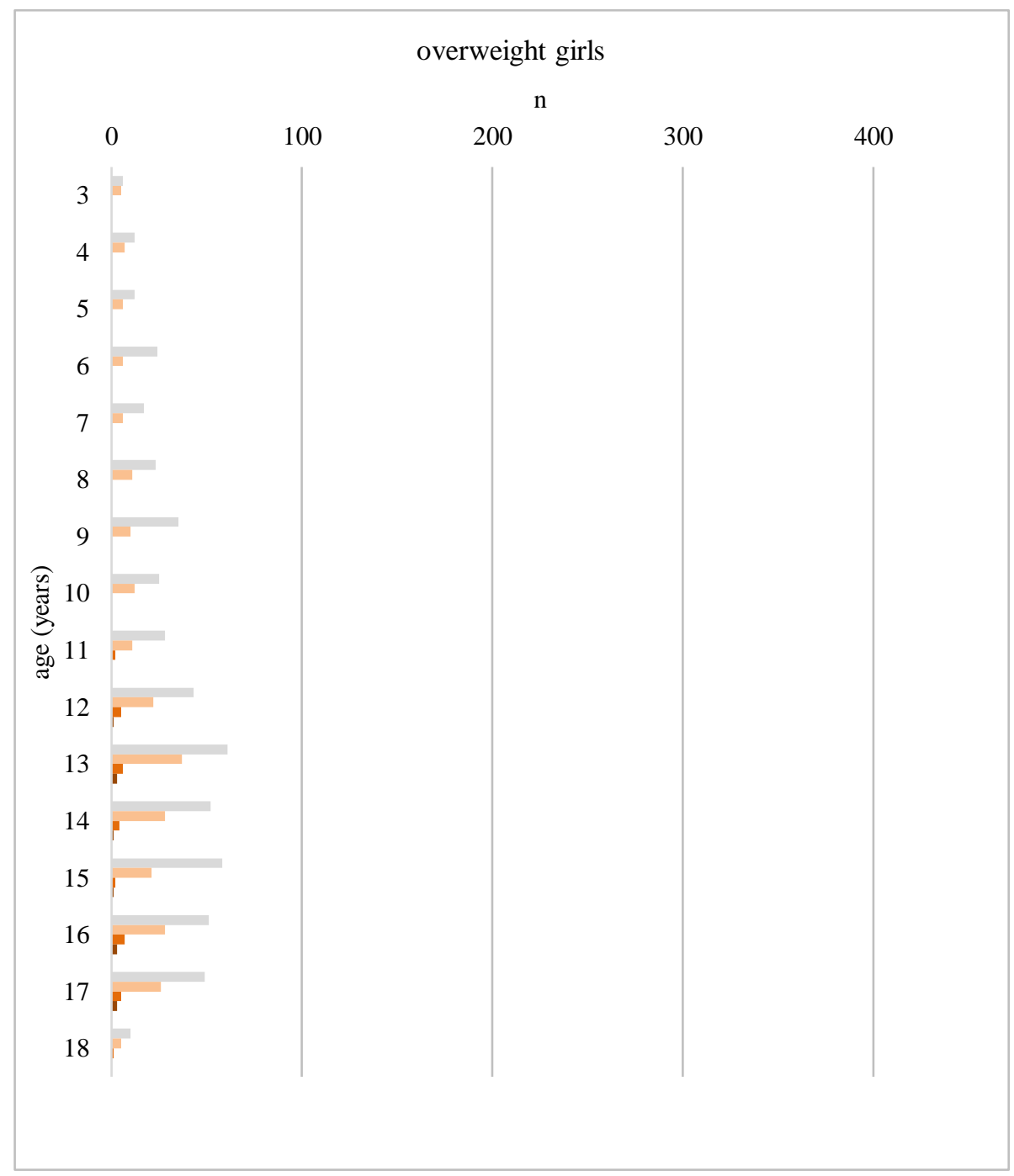

- proposed examination 


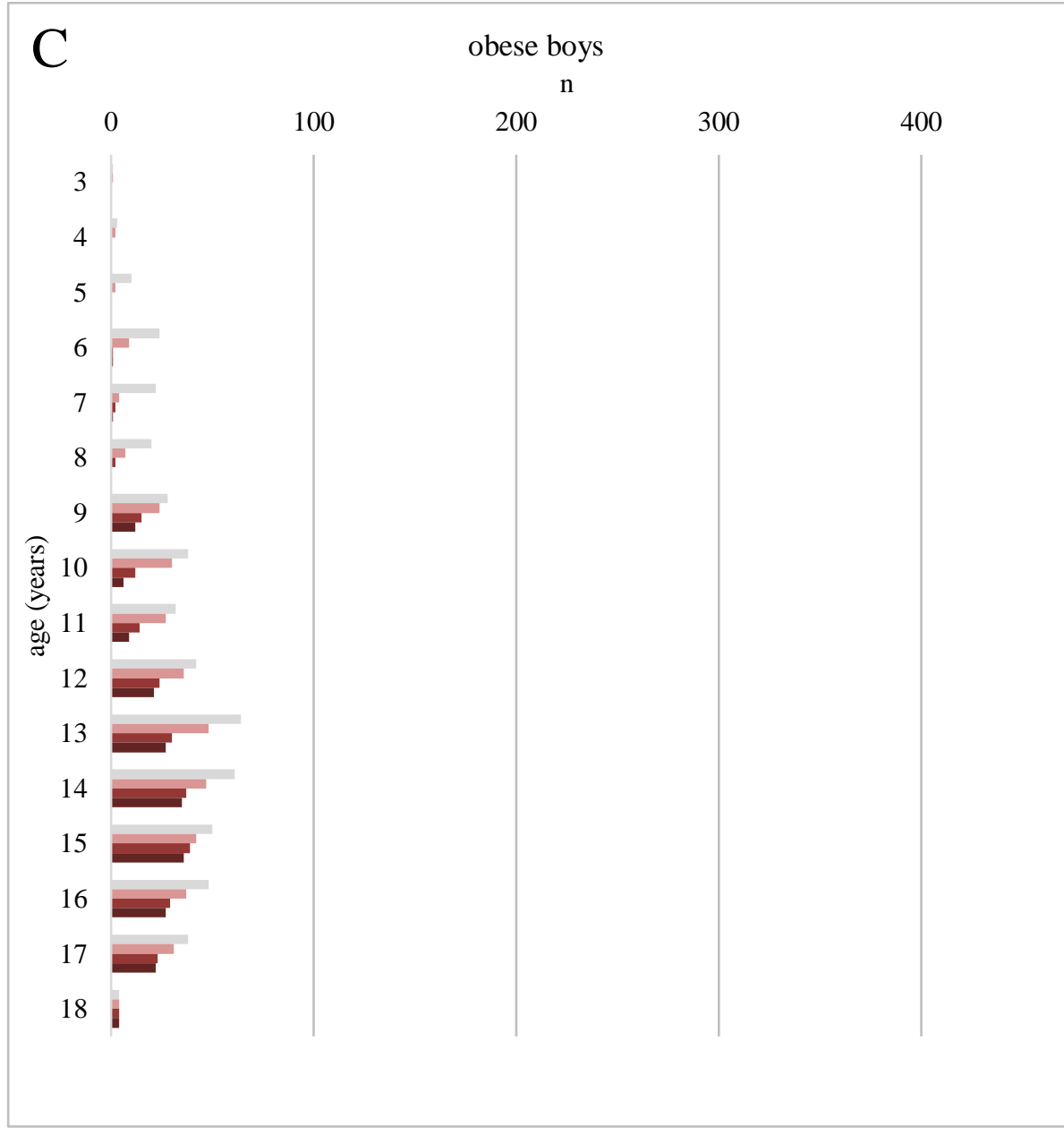

all patients

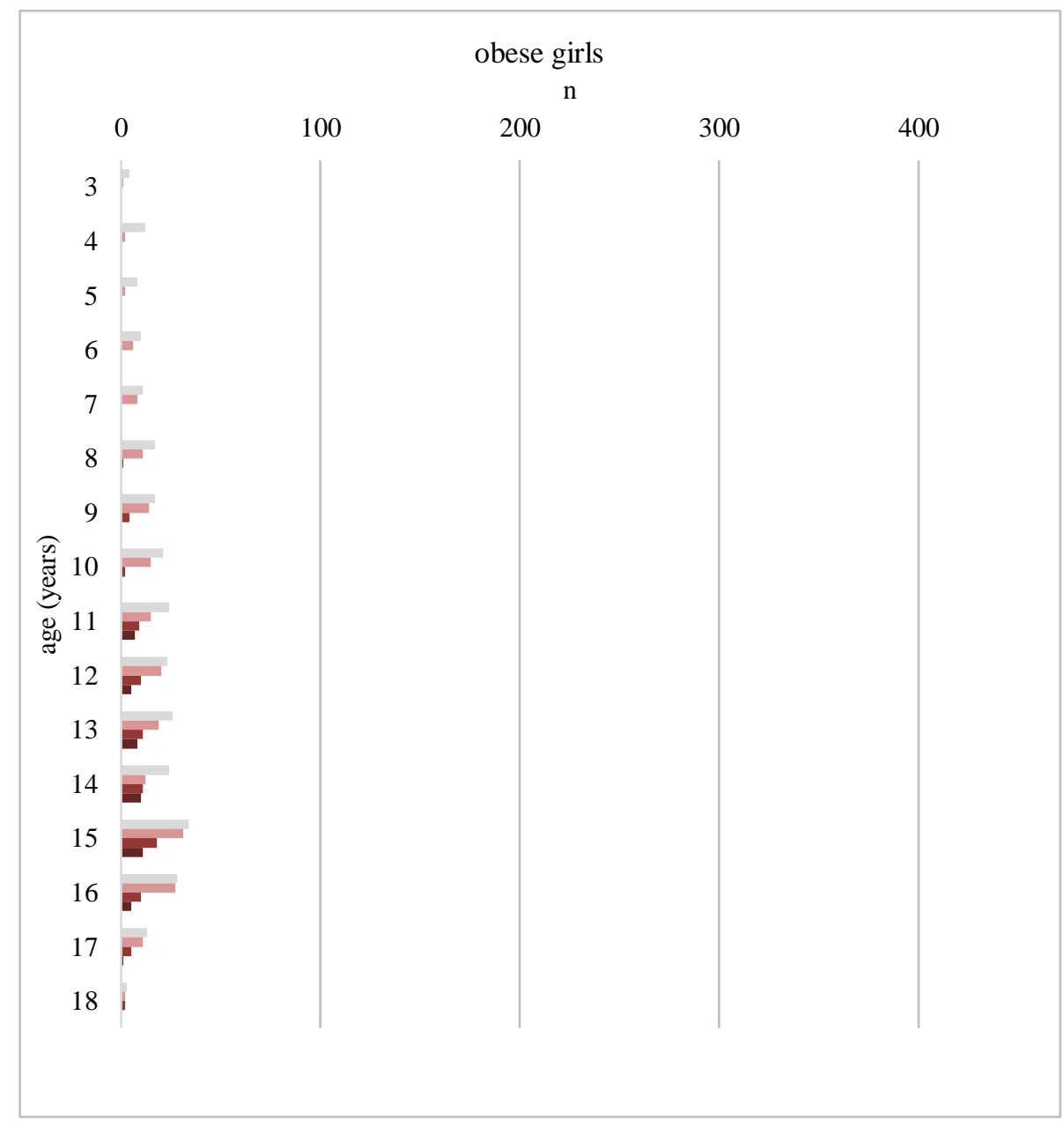

- proposed examination
- elevated / high BP based on ABPM

Figure 4 Distribution of elevated / high blood pressure at first measurement, proposed examination and elevated /or high blood pressure based on ABPM in different age groups in both sexes among normal weighted (A), overweight (B) and obese subjects (C) 
Figure 5 represents the numbers of subjects with normal, elevated BP and hypertension in OW and $\mathrm{O}$ subgroups in boys (5/A) and girls (5/B). From $725 \mathrm{OW}$ boys 86 and from $520 \mathrm{O}$ boys 156 proved to have hypertension. From $506 \mathrm{OW}$ girls 12, from 275 O 117 subjects were diagnosed with hypertension. Elevated BP was observed in 117 cases among OW boys, and 35 among $\mathrm{O}$ boys. Interestingly, in girls no elevated BP was found after the examination.

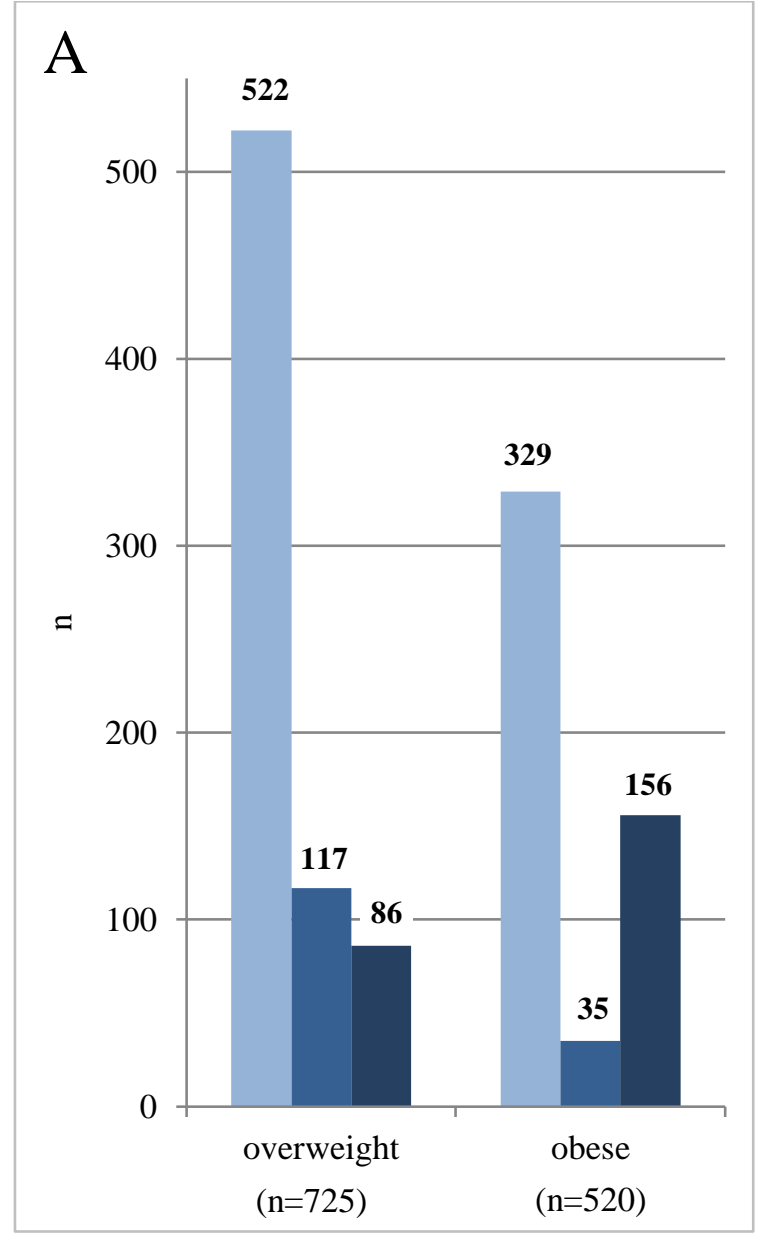

normal BP

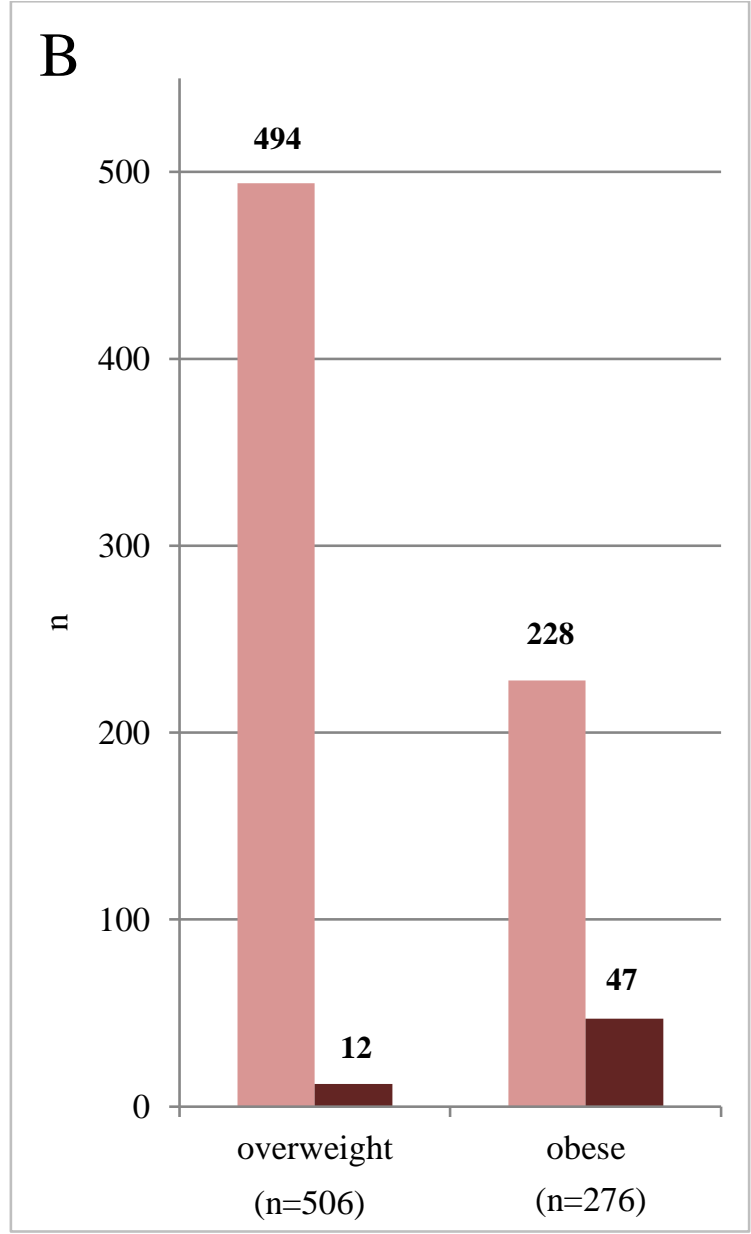

elevated BP

HTN

Figure 5 Distribution of normal BP, elevated BP and hypertension in OW and O subgroups in boys (A) and girls (B)

BP; blood pressure, OW; overweight, $\mathrm{O}$; obese, $\mathrm{n}$; number of patients

Figure 6 provides the summary of the distribution of normal BP, elevated BP and hypertension percentages in different weight categories. From this graph we can see that in boys hypertension was identified in $1.3 \%-12.7 \%-32.2 \%$ of the subjects in $\mathrm{N}$, OW and $\mathrm{O}$ groups respectively (6/A). In girls hypertension was diagnosed in $0.2 \%-2.4 \%-17.1 \%$ of the individuals, in N, OW and $\mathrm{O}$ groups respectively (6/B). Both in OW and $\mathrm{O}$ boys the prevalence of HTN was significantly higher compared to girls ( $p<0.0001)$. In both genders, the frequency of HTN was $8.3 \%$ in OW patients, and $26.7 \%$ in O patients $(6 / \mathrm{C})$. The rate of elevated BP was 
$0.6 \%-17.3 \%$ and $7.2 \%$ in $\mathrm{N}$, OW and $\mathrm{O}$ boys respectively. In $\mathrm{N}$ girls this rate was $0.1 \%$, surprisingly there was no patient with elevated BP in OW or O girls. Considering the whole investigated population, elevated BP was identified in $0.4 \%$ of $\mathrm{N}, 9.8 \%$ of $\mathrm{OW}$ and $4.6 \%$ in $\mathrm{O}$ patients.

normal weighted

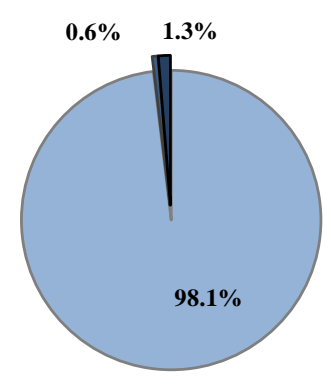

$\mathrm{B}$

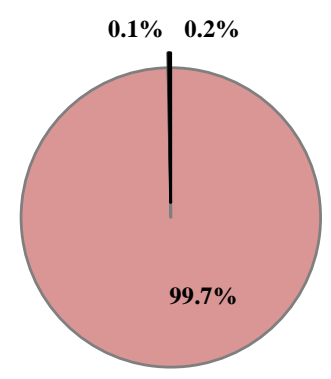

$\mathrm{C}$

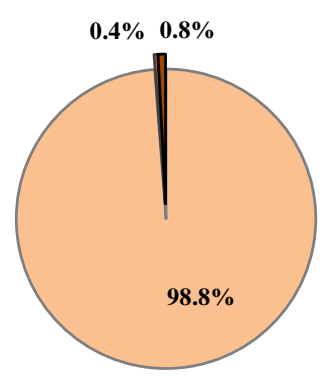

normal BP boys
normal BP girls
normal BP total overweight
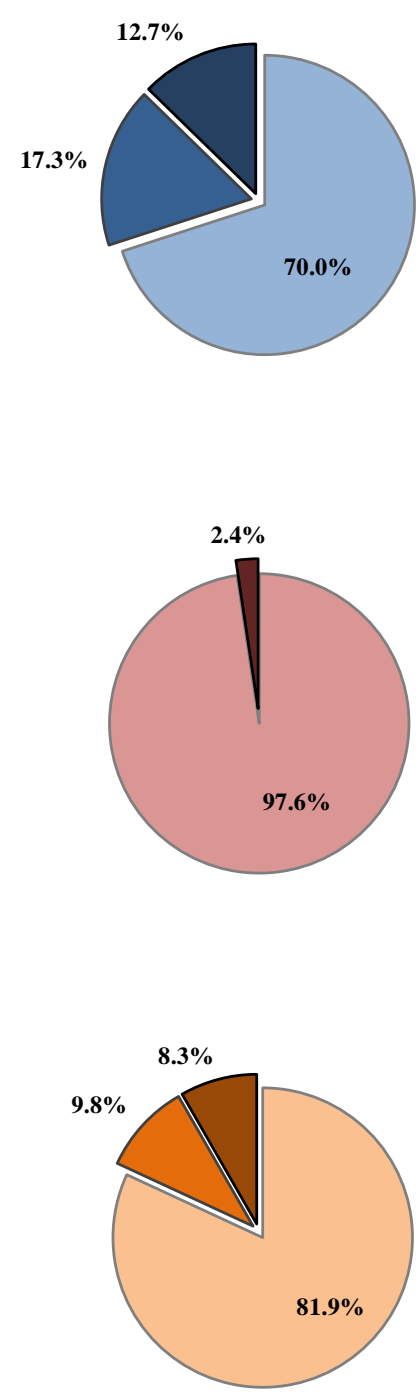

- elevated BP boys

- elevated BP girls

- elevated BP total obese
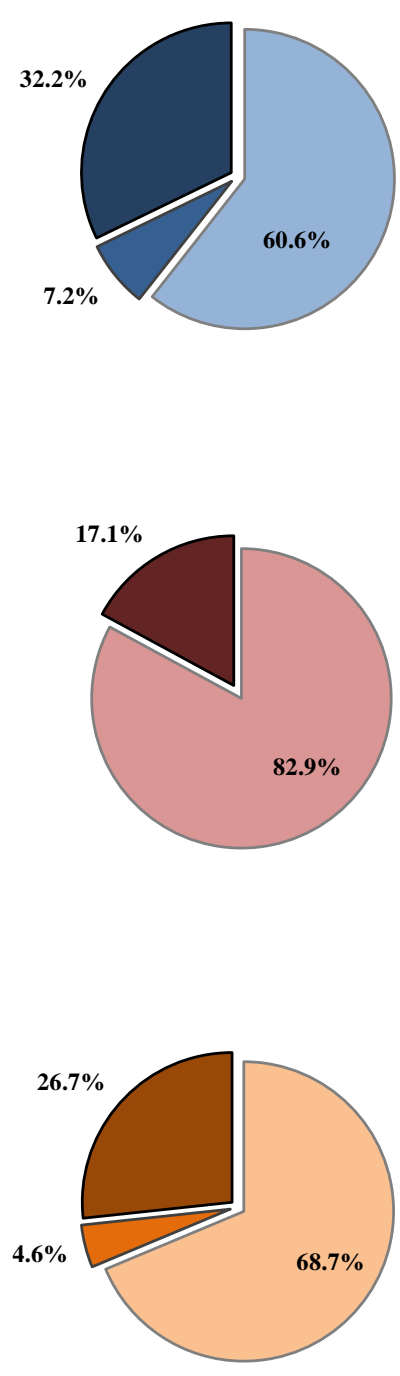

- HTN boys

- HTN girls

- HTN total

Figure 6 Prevalence of normal BP, elevated BP and HTN in N, OW and O boys (A), girls (B) and in the total population $(\mathbf{C})$;

BP; blood pressure, HTN; hypertension, N; normal weight, OW; overweight, O; obese 
Figure 7 presents and overview of HTN frequency in the examined population.

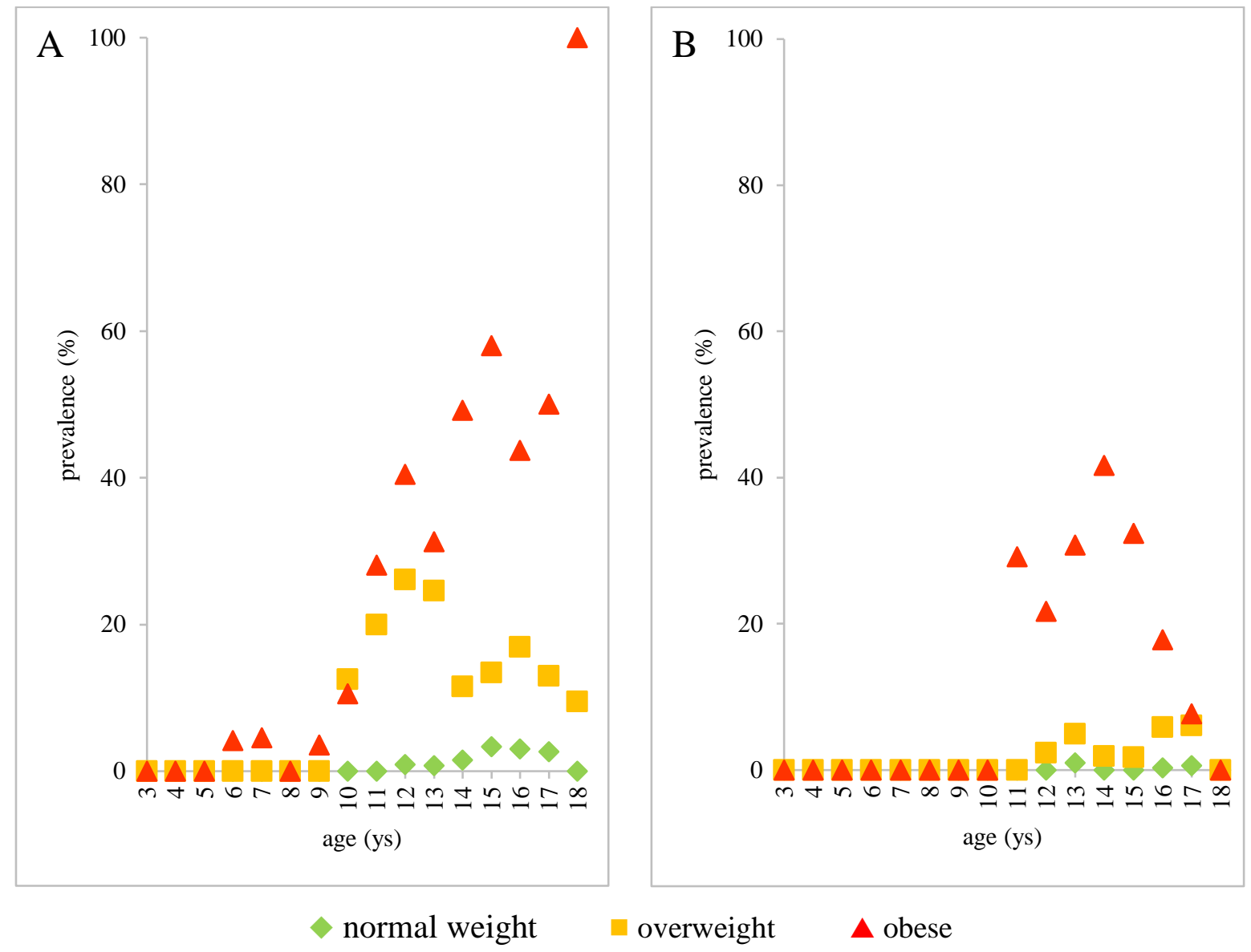

Figure 7 Distribution of HTN in normal, overweight and obese children based on their age (A: boys, B: girls)

As can be seen, in $\mathrm{N}$ boys the prevalence of HTN was the highest between the ages of 15 and 17, and between the ages of 13 and 14 in $\mathrm{N}$ girls. In OW boys the peak was between the ages of 11 and 13 years, and in OW girls aged 16 to 17. In O groups, HTN was most common in 1418-year-old and in 13-15-year-old girls.

Results from the statistical analysis of the HTN prevalence between boys and girls in different ages are presented in Table 2. 
Table 2 Comparison of high blood pressure prevalence values between sex, age and weight categories (Student's t-test)

\begin{tabular}{cccc} 
age & \multicolumn{3}{c}{ boys } \\
\cline { 2 - 4 } (years) & $\begin{array}{c}\text { overweight vs } \\
\text { normal } \\
\text { weight }\end{array}$ & $\begin{array}{c}\text { obese } \\
\text { vs normal } \\
\text { weight }\end{array}$ & $\begin{array}{c}\text { overweight vs } \\
\text { obese }\end{array}$ \\
\hline
\end{tabular}

$\begin{array}{lccc}\mathbf{3} & - & - & - \\ \mathbf{4} & - & - & - \\ \mathbf{5} & - & - & - \\ \mathbf{6} & - & \mathrm{p}<0.0001 & \mathrm{p}<0.0001 \\ \mathbf{7} & - & \mathrm{p}<0.0001 & \mathrm{p}<0.0001 \\ \mathbf{8} & - & - & - \\ \mathbf{9} & - & \mathrm{p}<0.0001 & \mathrm{p}<0.0001 \\ \mathbf{1 0} & \mathrm{p}<0.0001 & \mathrm{p}<0.0001 & \mathrm{p}<0.0001 \\ \mathbf{1 1} & \mathrm{p}<0.0001 & \mathrm{p}<0.0001 & \mathrm{p}<0.0001 \\ \mathbf{1 2} & \mathrm{p}<0.0001 & \mathrm{p}<0.0001 & \mathrm{p}<0.0001 \\ \mathbf{1 3} & \mathrm{p}<0.0001 & \mathrm{p}<0.0001 & \mathrm{p}<0.0001 \\ \mathbf{1 4} & \mathrm{p}<0.0001 & \mathrm{p}<0.0001 & \mathrm{p}<0.0001 \\ \mathbf{1 5} & \mathrm{p}<0.0001 & \mathrm{p}<0.0001 & \mathrm{p}<0.0001 \\ \mathbf{1 6} & \mathrm{p}<0.0001 & \mathrm{p}<0.0001 & \mathrm{p}<0.0001 \\ \mathbf{1 7} & \mathrm{p}<0.0001 & \mathrm{p}<0.0001 & \mathrm{p}<0.0001 \\ \mathbf{1 8} & \mathrm{p}<0.0001 & - & \mathrm{p}<0.0001\end{array}$

\begin{tabular}{ccc}
\multicolumn{3}{c}{ girls } \\
\hline $\begin{array}{c}\text { overweight vs } \\
\text { normal } \\
\text { weight }\end{array}$ & $\begin{array}{c}\text { obese } \\
\text { vs normal } \\
\text { weight }\end{array}$ & $\begin{array}{c}\text { overweight vs } \\
\text { obese }\end{array}$ \\
\hline
\end{tabular}

\begin{tabular}{ccc} 
weight & weight & - \\
\hline- & - & - \\
- & - & - \\
- & - & - \\
- & - & - \\
- & - & - \\
- & - & - \\
- & - & - \\
- & - & $p<0.001$
\end{tabular}

$\begin{array}{ccc}- & \mathrm{p}<0.0001 & \mathrm{p}<0.0001 \\ \mathrm{p}<0.0001 & \mathrm{p}<0.0001 & \mathrm{p}<0.0001 \\ \mathrm{p}<0.0001 & \mathrm{p}<0.0001 & \mathrm{p}<0.0001 \\ \mathrm{p}<0.0001 & \mathrm{p}<0.0001 & \mathrm{p}<0.0001 \\ \mathrm{p}<0.0001 & \mathrm{p}<0.0001 & \mathrm{p}<0.0001 \\ \mathrm{p}<0.0001 & \mathrm{p}<0.0001 & \mathrm{p}<0.0001 \\ \mathrm{p}<0.0001 & \mathrm{p}<0.0001 & \mathrm{p}<0.0001 \\ - & - & -\end{array}$

\begin{tabular}{ccc}
\multicolumn{3}{c}{ boys vs girls } \\
\hline $\begin{array}{c}\text { normal } \\
\text { weight }\end{array}$ & overweight & obese \\
\hline- & - & - \\
- & - & - \\
- & - & - \\
- & - & $\mathrm{p}<0.0001$ \\
- & - & $\mathrm{p}<0.0001$ \\
- & - & - \\
- & - & $\mathrm{p}<0.0001$ \\
- & $\mathrm{p}<0.0001$ & $\mathrm{p}<0.0001$ \\
- & $\mathrm{p}<0.0001$ & $\mathrm{NS}$ \\
$\mathrm{p}<0.0001$ & $\mathrm{p}<0.0001$ & $\mathrm{p}<0.0001$ \\
$\mathrm{NS}$ & $\mathrm{p}<0.0001$ & $\mathrm{NS}$ \\
$\mathrm{p}<0.0001$ & $\mathrm{p}<0.0001$ & $\mathrm{p}<0.0001$ \\
$\mathrm{p}<0.0001$ & $\mathrm{p}<0.0001$ & $\mathrm{p}<0.0001$ \\
$\mathrm{p}<0.0001$ & $\mathrm{p}<0.0001$ & $\mathrm{p}<0.0001$ \\
$\mathrm{p}<0.0001$ & $\mathrm{p}<0.0001$ & $\mathrm{p}<0.0001$ \\
- & $\mathrm{p}<0.0001$ & - \\
& &
\end{tabular}


Data from table shows us, that the frequency of HTN was statistically higher $(\mathrm{p}<0.0001)$ in OW and $\mathrm{O}$ patients compared to $\mathrm{N}$ patients in both genders. Furthermore, this prevalence is even higher in O patients compared to OW age groups. Due to the lack of HTN individuals in some age groups, statistical analysis was not applied in these categories (marked as “_" in Table 2).

Underlaying causes of HTN in the examined patients were heterogeneous: in one case cardiological (17-year-old girl, coarctation of aortae); in one case endocrinological (14-yearold girl, hyperthyroidism). In 34 cases clinical admission was suggested based on abnormal ultrasound findings of the kidneys (cysts, dilatation of upper collecting system). Finally, from these patients in 26 cases no nephrogenic cause was observed in the background of the HTN and in 8 cases no feedback was received about the final diagnose. 


\section{Discussion}

\section{Prevalence of Overweight and Obesity}

The prevalence of overweight and obesity is constantly increasing in children, adolescents, and adults, in developed and developing countries, as well [4]. This condition - beside several other profound consequences - raises the risk of cardiovascular mortality, thus on the one part substantially shortens life expectancy for persons, and on the other part, imposes a burden on health care and social welfare systems. Between 1975 and 2016 the global mean BMI raised from $16.8 \mathrm{~kg} / \mathrm{m}^{2}$ to $18.5 \mathrm{~kg} / \mathrm{m}^{2}$ in boys, and from $17.2 \mathrm{~kg} / \mathrm{m}^{2}$ to $18.6 \mathrm{~kg} / \mathrm{m}^{2}$ in girls. The Hungarian mean BMI increased from $18.8 \mathrm{~kg} / \mathrm{m}^{2}$ to $20.0 \mathrm{~kg} / \mathrm{m}^{2}$ in boys, and from $18.2 \mathrm{~kg} / \mathrm{m}^{2}$ to $19.9 \mathrm{~kg} / \mathrm{m}^{2}$ in girls [4]. In the ranking of 200 countries -where $1^{\text {st }}$ place means the most overweight or obese country-, regarding mean BMI in boys, Hungary moved to the $65^{\text {th }}$ place (2016) from the $23^{\text {rd }}(1975)$, and from $79^{\text {th }}$ (1975) to $70^{\text {th }}$ (2016) place in girls. In the same ranking, but regarding overweight, Hungarian boys are at the $50^{\text {th }}$ place (from the $46^{\text {th }}$ place) and girls stepped down to the $99^{\text {th }}$ place from $78^{\text {th }}$ place. In the case of obesity, Hungarian boys are on the $51^{\text {st }}$ place (from $54^{\text {th }}$ ) and girls became $85^{\text {th }}$ from $64^{\text {th }}$. Nauru, Cook Islands and Paulu are in the top three in the rank of overweight and obesity, meanwhile Vietnam, Cambodia, India, Burkina Faso and Nepal are represented in the last 5 positions on these lists [4]. In 2016, the mean BMI in the World was $18.5 \mathrm{~kg} / \mathrm{m}^{2}$ in girls and $18.6 \mathrm{~kg} / \mathrm{m}^{2}$ in boys, compared to $19.9 \mathrm{~kg} / \mathrm{m}^{2}$ and $20.0 \mathrm{~kg} / \mathrm{m}^{2}$ in Hungarian girls and boys, respectively.

Studies have suggested that there is a strong correlation between elevated BMI and geographical location, local habits and traditions, socio-economic culture, considering eating habits as well as physical activity patterns $[49,50]$. Changes in environmental factors, lifestyle, eating habits and in physical activity may affect the prevalence of overweight and obesity in a negative or positive way, as well. Such changes and the geo-economical differences justify the repeat of large population studies, in order to follow-up potential changes in the frequency of overweight and obesity. For this purpose, several studies have been carried out in Europe involving more than 10 European countries, including Hungary.

Between 2002 and 2006 in the "HELENA" study [51] adolescents (aged 12.5 - 17.5 years), between 2006 and 2012 in the "IDEFICS" [52] study children (aged 2 - 9 years), and between 2010 and 2013 in the "ENERGY" study [53] children aged 10-12 years were assessed. These three projects cover a remarkable period of time (>11 years). Antal and her co-workers have conducted their study in the first semester of the academic year 2005/2006 [57]. Our research 
lasted for 3 years, and the 3-18-year-old population was basically assessed simultaneously. Due to such circumstances, our findings may give a more accurate picture of the condition of a well-balanced, young generation with significant number $(n=6.824)$ of participants. Figure 8 represents our findings compared with the data previously measured in IDEFICS and in the study of Antal and her co-workers in Hungary [52,54].

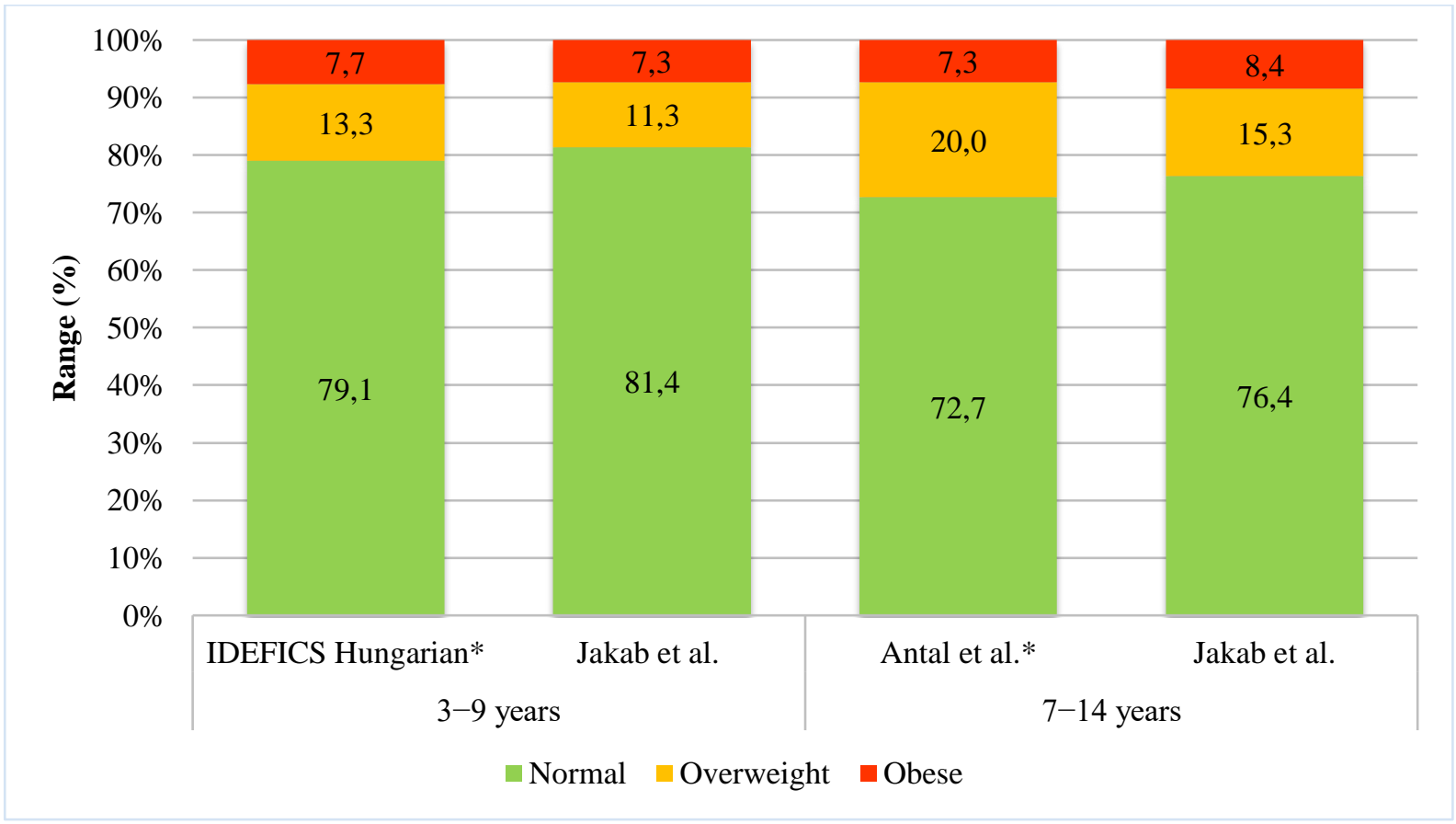

Figure 8 Comparison of normal weight, overweight and obesity prevalence between European data

[52], latest Hungarian data [54] and results from this study

To ensure the comparability of the data, our data have been determined in accordance with the age groups applied in the previous studies (3-9 years, 7-14 years). Since prevalence is available only in percentages in the HELENA and ENERGY studies and absolute numbers regarding Hungary are not published therein, the proper statistical analysis in these cases could not be applied. Statistically, compared to the previous Hungarian data, there has been no changes in any of the sexes, in any respect (Fisher's exact test, overweight $p=0.055$ and obesity $p=0.66$ ) in the youngest age group (3-9 years). However, a slight decrease is observed in the prevalence, since the p-value of the overweight is relatively close to the level of significance. In contrast, a significant decrease is presented in the older age group (7-14 years), in both sexes, with respect to overweight: the total prevalence has decreased from $20 \%$ to $15.3 \%(\mathrm{p}<0.005)$, while in this age group the prevalence of normal BMI increased from $72.7 \%$ to $76.4 \%$ ( $\mathrm{p}<0.001$ ), and no difference is presented in the case of obesity $(\mathrm{p}=0.2)$. Prevalence of OW/O in the studied population is detailed in Table 1. 
In our study, the prevalence of overweight and obesity was significantly higher in boys than in girls. Our findings essentially correspond to the global prevalence published by $\mathrm{Ng}$ and her coworkers [3]. BMI differences between the sexes have long been recognized [55]. Such differences may arise from biological, sociological and cultural differences, or perhaps from the combined effect of these $[56,57]$. There is a close correlation between the total energy expenditure (TEE) and body weight [58]. Goran and his co-workers found in their longitudinal study, that between the age of 5 to 10 years TEE is continuously increasing in case of boys, however in case of girls, this marker rises from 1,400 kcal (at age 5) to 1,800 kcal (at age 6) and falls to $1,600 \mathrm{kcal}$ (at age 9). This significant decrease is due to the fact that the girls' physical activity decreases by 50\% between the age 6 to 9 years [59]. Studies have found that adolescent girls are more likely to give attention to healthy nutrition, whilst boys are more apt to consume more fast food. These differences may stem from the Western societies' perception of the ideal body figure and from the fact that certain foods are gendered. For example, power and virility is symbolized by meat, therefore men eat more meat than women, while fat and carbohydrate rich foods are more often consumed by women in accordance with their menstrual cycle [60].

The above described reasons may explain the age-related increase in prevalence of overweight and obesity, namely that it increases between the age of 3 and 10 in both sexes, and afterwards shows a gradual decrease in both sexes; however, such decrease is more significant in case of girls.

One of the most important observation of this study is that compared to the previous Hungarian data, mild decrease occurred in the youngest age group (3-9 years) in both sexes, in respect of overweight. Furthermore, the prevalence of overweight significantly decreased, while the prevalence of normal BMI significantly increased in the older age group (7-14 years).

The interesting fact that the total prevalence of overweight and obesity has not significantly changed in the age group 3-9 year compared to the previous Hungarian data, may be explained by several factors. The lower supply of protein from human milk ( 9 and $10 \mathrm{~g} / \mathrm{d}$ at ages 3 and 6 month) as compared with formula (14 and $18 \mathrm{~g} / \mathrm{d}$, respectively) [61] might attenuate both early weight gain and later obesity [62]. One of the best predictors of later obesity risk is weight gain during the first year of life [63-65]. Recent studies have pointed out that increased protein intake ( $+6-8 \mathrm{~g}$ daily) during the first year of life could lead to 2.43 times higher risk for obesity at the age of 6 [66]. Moreover, the daily rhythm of nutrition of this age group is not wellbalanced, some meals are often omitted, which may also increase the risk of obesity [67]. Since parents have the greatest influence on nutrition at this age, they may have a key role at 
eliminating these anomalies. Consequently, education of parents in the field of nutrition is crucial, since they are the ones who are mostly responsible for the daily eating routine of their children.

Recognising these factors, several acts have been adopted in Hungary aimed to prevent obesity in childhood (daily physical education, regulation of the products offered at the school buffet, maximized trans-fatty acids in products).

When examining the prevalence of these conditions in other European countries we have found that in Switzerland the total prevalence of overweight and obesity shows a significant decline, due to the school-based promotion of physical activity and healthy nutrition. In France and Sweden data demonstrate that the raising trend has stopped, similarly to the United Kingdom, where it has reached its peak in 2005 (26.4\%) and no notable change was observed until 2008 [68].

Detailed interview questionnaire (physical activity patterns and nutritional habits) that is required to assess the progress examined, and measurement of hip and waist circumference, and upper arm skinfold thickness are planned in the future. These can give us more informative results, which could help in understanding the changes in the prevalence of increased BMI.

\section{Prevalence of Overweight and Obesity Associated Hypertension}

Juvenile hypertension affects males in majority, the prevalence is $5.5 \%$ in Caucasian males between the ages of 18 and 29 years, and $0.8 \%$ in females [69]. Roberts highlights the fact that this differentiation starts at the ages of 12 to 17 [70], caused by genetical and biological triggers and lasts until menopause [71]. A possible explanation for this finding might be that boys compared to girls - reaches greater body height and weight during puberty, and this anabolic demand could only be balanced via increased cardiac output by the cardiovascular system. This might lead to disproportion between the peripheral vascular volume and increased cardiac output resulting in increased or elevated BP. Furthermore, $\mathrm{OW}$ and $\mathrm{O}$ are more common in boys and increased amount of adipose tissue raises BP via numerous pathophysiological pathways, these facts will lead to the higher prevalence of HTN in boys compared to girls. Researchers from the Pediatric Department from the University of Pécs published Hungarian data on O associated HTN in children [72,73]. Csábi and her co-workers established the prevalence of metabolic cardiovascular syndrome in O adolescents. In their analysis of $103 \mathrm{O}$ boys, HTN was confirmed in $39.8 \%$, whereas in $77 \mathrm{O}$ girls, HTN was observed in $41.6 \%$ based on 24-hoursABPM results [72]. In an investigation into circadian rhythm of BP, Török and her co-workers took 24-hours-ABPM measurements in 73 children and based on their diurnal index (DI) 
divided the subjects into "dipper" (DI is $10 \%<$ ) and "non-dipper" (DI is $>10 \%$ ) groups. They found that HTN was more common in the non-dipper group (83.9\%) compared to the dipper group (45.2\%) [73]. Csábi and Török reported higher prevalence of O associated HTN, than described in our study. This might stem from the difference of the included subjects: both studies [72,73] enrolled patients from the obesity outpatient clinic, in contrast with our normal population. Much of the available literature on OW and $\mathrm{O}$ associated HTN deals with the question of the frequency in children and adolescents. Analysing the current literature we collected the most relevant articles, based on the following including criteria: timing of the study (between 2005 and 2018), number of cases (minimum as much cases as in our research), published odds ratio (OR), to understand how OW and $\mathrm{O}$ rise the risk for HTN in this population. Outlines of the finally included articles are shown in Table 3. 
Table 3 Comparison of our results with those of two earlier-published large-population studies

\begin{tabular}{|c|c|c|c|c|c|}
\hline & $\begin{array}{c}\text { normal BP } \\
\left(<90^{\text {th }} \text { percentile }\right) \\
\text { n / \% }\end{array}$ & $\begin{array}{c}\text { elevated BP } \\
\left(\geq 90^{\text {th }}-<95^{\text {th }}\right. \\
\text { percentile }) \\
n / \%\end{array}$ & $\begin{array}{c}\text { high BP } \\
\left(\geq 95^{\text {th }} \text { percentile }\right) \\
n / \%\end{array}$ & $\begin{array}{l}\text { odds ratio } \\
(95 \% \mathrm{CI})\end{array}$ & nationality \\
\hline \multicolumn{6}{|l|}{ Lu et al; 2013 [74] } \\
\hline $\begin{array}{l}\text { overweight } \\
(\mathrm{n}=10.252)\end{array}$ & $8890 / 86.1$ & No data & $1362 / 13.9$ & 1.67 & \multirow{2}{*}{ Chinese } \\
\hline $\begin{array}{l}\text { obese } \\
(\mathrm{n}=7.397)\end{array}$ & $5797 / 78.4$ & No data & $1600 / 21.6$ & 2.17 & \\
\hline \multicolumn{6}{|l|}{ Lo et al; 2014 [33] } \\
\hline $\begin{array}{l}\text { overweight } \\
(n=11.016)\end{array}$ & 9454 / 65.6 & $3402 / 23.6$ & $1562 / 10.8$ & $1.5(0.9-2.3)$ & \multirow{2}{*}{ American } \\
\hline obese $(n=4.582)$ & $3348 / 51.6$ & $1906 / 29.4$ & $1234 / 19.0$ & $\begin{array}{l}1.8(1.1-3.0) \\
3.5(2.1-5.8) \\
5.7(3.6-8.9)\end{array}$ & \\
\hline \multicolumn{6}{|l|}{ Jakab et al; 2019} \\
\hline $\begin{array}{l}\text { overweight } \\
(\mathrm{n}=1.231)\end{array}$ & $1016 / 81.9$ & $117 / 9.8$ & $98 / 8.3$ & $1.1(0.8-1.3)$ & \multirow[t]{2}{*}{ Hungarian } \\
\hline obese $(n=795)$ & 557 / 68.7 & $35 / 4.6$ & $203 / 26.7$ & $3.6(3.0-4.3)$ & \\
\hline
\end{tabular}


Lu et al. in 2009 completed a prospective, cross-sectional study in China (Shanghai) involving a total of 78.114 children (7-14 years) [74]. BP was measured only once with mercury sphygmo-manometer. There is no available data on patients with elevated BP. Prevalence of HTN was $13.9 \%$ in OW patients (OR: 1.67) and 21.6\% in O patients (OR: 2.17).

Between 2007 and 2010 Lo et al. analysed data of 117.618 children and adolescents (6-17 years) in a retrospective, cross-sectional study. In this research, BP was measured once with an oscillometric device, repeating the measurement if needed (elevated SBP and/or DBP) [33]. Obese children were further classified into 3 different subgroups on BMI expressed as a percentage above the 95th BMI percentile according to age and sex. In this study, the frequency of elevated BP was $23.6 \%$ among OW patients, and $29.4 \%$ among $\mathrm{O}$ patients. Furthermore, prevalence of HTN was $10.8 \%$ in OW subjects, whereas it was $19 \%$ in O patients (OR: 1.8-3.55.7).

In our study this rate was $8.3 \%$ in $\mathrm{OW}$ and $26.7 \%$ in $\mathrm{O}$ patients. Our findings show a great accordance with the above mentioned results, however, minor discrepancies may origin from the following methodical difference: on one hand, in the Chinese study local reference values were used to categorize subjects based on their BP [75], on the other hand, in the American study the reference values published in 2004 and revised in 2012 were applied [43]. In the study conducted by us European cut-off values were adopted to create subgroups based on BP $[47,48]$.

Surprisingly, after the detailed examination we did not found any patient with elevated BP in OW or O girls. The underlying causes for this could be the fact, that HTN is a more common morbidity in boys compared to girls $[69,70]$. Secondly, total number of OW and O girls was markedly lower than in boys. Lastly, prevalence of HTN was even lower in OW and O girls. These factors may lead to the observed result, which is considered to an accidental finding. Hereby we highlight the fact that in $\mathrm{N}$ girls in 3 cases elevated BP was diagnosed.

OW, O and associated HTN is a major public health problem, since the rising frequency of OW and $\mathrm{O}$ consequently increases the incidence of HTN in these patients. Nowadays, it is suggested to closely follow-up patients with $\mathrm{OW}, \mathrm{O}$ in order to monitor possible comorbidities, and supporting them in a body weight reducing lifestyle, finally, if needed treating them appropriately. However, the final goal should be proper primary prevention targeting these abnormal conditions. 


\section{Summary}

A summary of the main findings and of the principal issues which have arisen in this thesis are the followings:

1. We have found the prevalence of overweight is $13.4 \%$ and $6.6 \%$ of obesity in Szolnok, in Hungary.

2. Overweight and obesity are more common in boys, than in girls $(\mathrm{p}<0.005)$.

3. Compared to the previous Hungarian data, we have identified a mild decrease in the youngest age group (3-9 years) in both sexes, in respect of overweight (2006-2012 vs 2012-2016). We have established, that the prevalence of overweight significantly decreased, while the prevalence of normal BMI significantly increased in the older age group (7-14 years) (2005-2006 vs 2012-2016).

4. Prevalence of overweight and obesity associated hypertension was $8.3 \%$, and $26.7 \%$ respectively.

5. Increased BMI associated hypertension was more common in boys. In overweight boys the peak was between the ages of 11 and 13 years, and in OW girls between 16 to 17. In O groups, HTN was most common in boys aged 14 to 18 , while 13 to 15 in girls.

6. Overweight raises the risk for hypertension (odds ratio: 1.1) not as much, as obesity, where the odds ratio is 3.6 .

7. Regarding the prevalence of overweight and obesity associated hypertension, our findings show a great accordance with the great, international, relevant and contemporary population studies. 


\section{References}

$1 \quad$ WHO | World Health Organization. WHO 2018.

2 Cole TJ, Lobstein T: Extended international (IOTF) body mass index cut-offs for thinness, overweight and obesity. Pediatr Obes 2012; 7:284-94.

3 Ng M, Fleming T, Robinson M, Thomson B, Graetz N, Margono C, et al.: Global, regional, and national prevalence of overweight and obesity in children and adults during 1980-2013: A systematic analysis for the Global Burden of Disease Study 2013. Lancet $2014 ; 384: 766-781$.

4 WHO: NCD-RisC 2016; http://www.ncdrisc.org/index.html

5 Tulassay T: Obesitas és metabolikus szindróma; in Tulassay $\mathrm{T}$ (ed): Klinikai Gyermekgyógyászat, ed 1st. Medicina, 2016, pp 534-535.

6 James O Hill and John C Peters: Environmental Contributions to the Obesity Epidemic. Science (80- ) 1998; 280:1371-1374.

7 Bowman SA, Gortmaker SL, Ebbeling CB, Pereira MA, Ludwig DS: Effects of FastFood Consumption on Energy Intake and Diet Quality Among Children in a National Household Survey. Pediatrics 2004; 113:112-118.

8 Mamun A Al, Lawlor DA, Cramb S, O’Callaghan M, Williams G, Najman J: Do childhood sleeping problems predict obesity in young adulthood? Evidence from a prospective birth cohort study. Am J Epidemiol 2007; 166:1368-1373.

9 Guo C, Zhou Q, Zhang D, Qin P, Li Q, Tian G, et al.: Total sedentary behavior and TV viewing with risk of overweight/obesity, type 2 diabetes, and hypertension: a doseresponse meta-analysis. Diabetes Obes Metab 2019;1-12.

10 Cutting TM, Fisher JO, Grimm-Thomas K, Birch LL: Like mother, like daughter: Familial patterns of overweight are mediated by mothers' dietary disinhibition. Am J Clin Nutr 1999; 69:608-613.

11 Spruijt-Metz D, Lindquist CH, Birch LL, Fisher JO, Goran MI: Relation between mothers' child-feeding practices and children's adiposity. Am J Clin Nutr 2002; 75:581586. 
12 Shah P, Misra A, Gupta N, Hazra DK, Gupta R, Seth P, et al.: Improvement in nutritionrelated knowledge and behaviour of urban Asian Indian school children: Findings from the Medical education for children/Adolescents for Realistic prevention of obesity and diabetes and for healthy aGeing (MARG) intervention study. Br J Nutr 2010; 104:427436.

13 French SA, Wechsler H: School-based research and initiatives: Fruit and vegetable environment, policy, and pricing workshop. Prev Med 2004; 39:101-107.

14 Davison KK, Lawson CT: Do attributes in the physical environment influence children's physical activity? A review of literature. Int J Behav Nutr Phys Act 2006; 3:19.

15 Timperio A, Ball K, Roberts R, Campbell K, Andrianopoulos N, Crawford D: Children's fruit and vegetable intake: Associations with the neighbourhood food environment. Prev Med 2008; 46:331-335.

16 Spence JC, Cutumisu N, Edwards J, Evans J: Influence of neighbourhood design and access to facilities on overweight among preschool children. Int J Pediatr Obes 2008; 3:109-116.

17 Swinburn B, Egger G, Raza F: Dissecting obesogenic environments: The development and application of a framework for identifying and prioritizing environmental interventions for obesity. Prev Med 1999; 29:563-570.

18 McGee DL: Body mass index and mortality: A meta-analysis based on person-level data from twenty-six observational studies. Ann Epidemiol 2005; 15:87-97.

19 Mahoney LT, Burns TL, Stanford W, Thompson BH, Witt JD, Rost CA, et al.: Coronary risk factors measured in childhood and young adult life are associated with coronary artery calcification in young adults: The Muscatine study. J Am Coll Cardiol 1996; 27:277-284.

20 Sorof J, Daniels S: Obesity hypertension in children: A problem of epidemic proportions. Hypertension 2002; 40:441-447.

21 Kaufman FR, Hirst K, Linder B, Baranowski T, Cooper DM, Foster GD, et al.: Risk factors for type 2 diabetes in a sixth-grade multiracial cohort: The HEALTHY study. Diabetes Care 2009; 32:953-955. 
22 Srinivasan SR, Myers L, Berenson GS: Temporal association between obesity and hyperinsulinemia in children, adolescents, and young adults: the Bogalusa Heart Study. Metabolism 1999; 48:928-34.

23 Weiss R, Djura J, Burgert TS, Tamborlane W V, Taksali SE, Yeckel CW, et al.: Obesity and the metabolic syndrome in children and adolescents. N Engl J Med 2004; 350:23622374.

24 Goran M, Gower B: Abdominal obesity and cardiovascular risk in children. Coron Artery Dis 1998; 9:483-487.

25 Marcus CL, Curtis S, Koerner CB, Joffe A, Serwint JR, Loughlin GM: Evaluation of pulmonary function and polysomnography in obese children and adolescents. Pediatr Pulmonol 1996; 21:176-183.

26 Loomba R, Sirlin C, Schwimmer JB, Lavine J: Advances in pediatric nonalcoholic fatty liver disease. Hepatology 2009; 50:1282-1293.

27 Dore MP, Maragkoudakis E, Fraley K, Pedroni A, Tadeu V, Realdi G, et al.: Diet, lifestyle and gender in gastro-esophageal reflux disease. Dig Dis Sci 2008; 53:20272032.

28 Scott AC, Kelly CH, Sullivan E: Body mass index as a prognostic factor in development of infantile Blount disease. J Pediatr Orthop 2007; 27:921-925.

29 Carpenter KM, Hasin DS, Allison DB, Faith MS: Relationships Between Obesity and DSM-IV Major Depressive Disorder, Suicide Ideation, and Suicide Attempts: Results From a General Population Study. Am J Public Heal J Public Heal 2000; 25190:251257.

30 Daniels S: The consequences of childhood overweight and obesity. Futur Child 2006; $16: 47-67$.

31 Chobanian A V., Bakris GL, Black HR, Cushman WC, Green LA, Joseph L. Izzo J, et al.: The Seventh Report of the Joint National Committee on Prevention, Detection, Evaluation, and Treatment of High Blood Pressure;The JNC 7 Report; Jama 2003; 289:2560.

32 Juonala M, Kelly R, Magnussen CG, Sabin MA, Cheung M: Development of hypertension in overweight adolescents: a review. Adolesc Health Med Ther 2015; 171. 
33 Lo JC, Chandra M, Sinaiko A, Daniels SR, Prineas RJ, Maring B, et al.: Severe obesity in children: prevalence, persistence and relation to hypertension. Int J Pediatr Endocrinol 2014; 2014:3.

34 Muntner P, Cutler JA, Wildman RP, Whelton PK: Trends in Blood Pressure Among Children and Adolescents. JAMA 2004; 291:2107-2113.

35 Yoshinaga M, Yuasa Y, Hatano H, Kono Y, Nomura Y, Oku S, et al.: Effect of total adipose weight and systemic hypertension on left ventricular mass in children. Am $\mathbf{J}$ Cardiol 1995; 76:785-797.

36 Daniels S R: Effect of lean body mass, fat mass, blood pressure and sexual maturation on left ventricular mass. Circulation 1995; 92:3254.

37 de Simone G, Devereux RB, Chinali M, Roman MJ, Lee ET, Resnick HE, et al.: Metabolic syndrome and left ventricular hypertrophy in the prediction of cardiovascular events: the Strong Heart Study. Nutr Metab Cardiovasc Dis 2009; 19:98-104.

38 Strong JP, Malcom GT, Mcmahan CA, Tracy RE, Iii WPN, Herderick EE, et al.: Prevalence and Extent of Atherosclerosis in Adolescents and Young Adults. JAMA $1999 ; 281: 727-35$.

39 Berenson GS, Srinivasan SR, Bao W, Newman W, Tracy R, Wattigney W: Association between multiple cardiovascular risk factors and atherosclerosis in children and young adults. The Bogalusa heart study. N Engl J Med 1998; 338:1650-1656.

40 Tulassay T: Klinikai Gyermekgyógyászat. ed 1 Medicina, 2016.

41 Horváth IG, Németh A, Lenkey Z, Alessandri N, Tufano F, Kis P, et al.: Invasive validation of a new oscillometric device (Arteriograph) for measuring augmentation index, central blood pressure and aortic pulse wave velocity. J Hypertens 2010; 28:206875.

42 Baulmann J, Schillings U, Rickert S, Uen S, Düsing R, Illyes M, et al.: A new oscillometric method for assessment of arterial stiffness: comparison with tonometric and piezo-electronic methods. J Hypertens 2008; 26:523-528.

43 National High Blood Pressure Education Program Working Group on High Blood Pressure in Children and Adolescents: The fourth report on the diagnosis, evaluation, and treatment of high blood pressure in children and adolescents. Pediatrics 2004; 114:555-576. 
44 Flynn JT, Kaelber DC, Baker-Smith CM: Clinical Practice Guideline for Screening and Management of High Blood Pressure in Children and Adolescents. Pediatrics 2018; 140(3):e20181739.

45 Schwandt P, Scholze JE, Bertsch T, Liepold E, Haas GM: Blood pressure percentiles in 22,051 German children and adolescents: The PEP family heart study. Am J Hypertens $2015 ; 28: 672-679$.

46 Reusz G, Szabó L, Kiss É: Guide for the treatment of hypertension in infants and childhood. Gyermekgyógyászat 2019; 70:109-120.

47 Soergel M, Kirschstein M, Busch C, Danne T, Gellermann J, Holl R, et al.: Oscillometric twenty-four-hour ambulatory blood pressure values in healthy children and adolescents: A multicenter trial including 1141 subjects. J Pediatr 1997; 130:178-184.

48 Lurbe E, Agabiti-Rosei E, Cruickshank JK, Dominiczak A, Erdine S, Hirth A, et al.: 2016 European Society of Hypertension guidelines for the management of high blood pressure in children and adolescents. J Hypertens 2016; 34:1887-1920.

49 Pérez Rodrigo C: Current mapping of obesity. Nutr Hosp 2013; 28:21-31.

50 Shugart HA: Weight of tradition: Culture as a rationale for obesity in contemporary U.S. news coverage. Obes Rev 2013; 14:736-744.

51 Moreno LA, De Henauw S, González-Gross M, Kersting M, Molnár D, Gottrand F, et al.: Design and implementation of the Healthy Lifestyle in Europe by Nutrition in Adolescence Cross-Sectional Study. Int J Obes 2008; 32:4-11.

52 Ahrens W, Pigeot I, Pohlabeln H, De Henauw S, Lissner L, Molnár D, et al.: Prevalence of overweight and obesity in European children below the age of 10. Int J Obes 2014; 38:99-107.

53 van Stralen MM, te Velde SJ, Singh AS, De Bourdeaudhuij I, Martens MK, van der Sluis M, et al.: EuropeaN Energy balance Research to prevent excessive weight Gain among Youth (ENERGY) project: Design and methodology of the ENERGY cross-sectional survey. BMC Public Health 2011; 11:65. 
54 Antal M, Péter S, Biró L, Nagy K, Regöly-Mérei A, Arató G, et al.: Prevalence of underweight, overweight and obesity on the basis of body mass index and body fat percentage in Hungarian schoolchildren: Representative survey in metropolitan elementary schools. Ann Nutr Metab 2009; 54:171-176.

55 Legato MJ: Gender-specific aspects of obesity. Int J Fertil Womens Med 1977; 42:184197.

56 Bird CE, Rieker PP: Gender matters: an integrated model for understanding men's and women's health. Soc Sci Med 1999; 48:745-755.

57 Krieger N: Genders, sexes, and health: what are the connections--and why does it matter? Int J Epidemiol 2003; 32:652-657.

58 Goran MI, Sun M: Total energy expenditure and physical activity in prepubertal children: recent advances based on the application of the doubly labeled water method. Am J Clin Nutr 1998; 68:944-949.

59 Goran MI: Metabolic precursors and effects of obesity in children: a decade of progress, 1990-1999. Am J Clin Nutr 2001; 73:158-171.

60 Lovejoy JC: The influence of sex hormones on obesity across the female life span. J women's Heal 1998; 7:1247-1256.

61 Alexy U, Kersting M, Sichert-Hellert W, Manz F, Schöch G: Macronutrient intake of 3to 36-month-old German infants and children: results of the DONALD Study. Dortmund Nutritional and Anthropometric Longitudinally Designed Study. Ann Nutr Metab 1999; 43:14-22.

62 Koletzko B: Early Nutrition and its Later Consequences: New Opportunities. Adv Exp Med Biol 2005; 569:1-12.

63 Monteiro PO a, Victora CG: Rapid growth in infancy and childhood and obesity in later life--a systematic review. Obes Rev 2005; 6:143-154.

64 Ong K, Loos R: Rapid infancy weight gain and subsequent obesity: Systematic reviews and hopeful suggestions. Acta Paediatr Int J Paediatr 2006; 95:904-908.

65 Druet C, Stettler N, Sharp S, Simmons RK, Cooper C, Davey Smith G, et al.: Prediction of childhood obesity by infancy weight gain: An individual-level meta-analysis. Paediatr Perinat Epidemiol 2012; 26:19-26. 
66 Weber M, Grote V, Closa-Monasterolo R, Escribano J, Langhendries JP, Dain E, et al.: Lower protein content in infant formula reduces BMI and obesity risk at school age: Follow-up of a randomized trial. Am J Clin Nutr 2014; 99:1041-1051.

67 Thibault H, Carriere C, Langevin C, Déti EK, Barberger-Gateau P, Maurice S: Prevalence and factors associated with overweight and obesity in French primary-school children. Public Health Nutr 2012; 16:1-9.

68 Nagy P, Erhardt É, Kovács É, Molnár D: Megfordult-e az elhízás terjedésének trendje az újabb vizsgálatok tükrében? Gyermekgyógyászat 2012; 3:31-35.

69 Cutler JA, Sorlie PD, Wolz M, Thom T, Fields LE, Roccella EJ: Trends in hypertension prevalence, awareness, treatment, and control rates in United States adults between 1988-1994 and 1999-2004. Hypertension 2008; 52:818-827.

70 Roberts J, Maurer K: Blood pressure levels of persons 6-74 years. United States, 19711974. Vital Health Stat 11 1977; 1-103.

71 Everett B, Zajacova A: Gender differences in hypertension and hypertension awareness among young adults. Biodemography Soc Biol 2015; 61:1-17.

72 Csábi G, Török K, Jeges S, Molnár D: Presence of metabolic cardiovascular syndrome in obese children. Eur J Pediatr 2000; 159:91-94.

73 Török K, Pálfi A, Szelényi Z, Molnár D: Circadian variability of blood pressure in obese children. Nutr Metab Cardiovasc Dis 2008; 18:429-435.

74 Lu X, Shi P, Luo C-Y, Zhou Y-F, Yu H-T, Guo C-Y, et al.: Prevalence of hypertension in overweight and obese children from a large school-based population in Shanghai, China. BMC Public Health 2013; 13:24.

75 Huo D, Hong C, TianYou W, Wang L, Zhao D, Zhang M, et al.: Study on relationship of blood pressure with BMI, FMP and waist circumference among children and adolescents in Beijing. Chinese J Pract Pediatr 2010; 524-527. 
Supplementary Table 1A/a Characteristics of normal weight, overweight and obese boys

\begin{tabular}{|c|c|c|c|c|c|c|c|c|c|c|c|c|c|c|c|c|c|c|c|c|c|}
\hline \multirow[b]{2}{*}{ (ys) } & \multicolumn{7}{|c|}{ normal weight } & \multicolumn{8}{|c|}{ overweight } & \multicolumn{6}{|c|}{ obese } \\
\hline & $\mathrm{n}$ & $\begin{array}{l}\text { weight } \\
(\mathrm{kg})\end{array}$ & $\begin{array}{l}\text { height } \\
(\mathrm{cm})\end{array}$ & $\begin{array}{c}\text { BMII } \\
\left(\mathrm{kg} / \mathrm{m}^{2}\right)\end{array}$ & $\begin{array}{c}\underset{(\mathrm{mmH}}{\mathrm{SBP}}) \\
\end{array}$ & $\begin{array}{c}\text { DBPbrach } \\
\text { (mmHg) }\end{array}$ & $\underset{(1 / \mathrm{min})}{\mathbf{H R}}$ & $\mathrm{n}$ & $\begin{array}{c}\text { weight } \\
(\mathrm{kg})\end{array}$ & $\begin{array}{l}\text { height } \\
(\mathrm{cm})\end{array}$ & $\begin{array}{c}\text { BMII } \\
\left(\mathrm{kg} / \mathrm{m}^{2}\right)\end{array}$ & $\begin{array}{c}\text { SBPbrach } \\
(\mathrm{mmHg})\end{array}$ & $\begin{array}{c}\text { DBPbrach } \\
(\mathrm{mmHg})\end{array}$ & $\underset{(1 / \min )}{\mathrm{HR}}$ & $\mathrm{n}$ & $\begin{array}{l}\text { weight } \\
(\mathrm{kg})\end{array}$ & $\begin{array}{l}\text { height } \\
(\mathrm{cm})\end{array}$ & $\begin{array}{c}\text { BMII } \\
\left(\mathrm{kg} / \mathrm{m}^{2}\right)\end{array}$ & $\begin{array}{c}\begin{array}{c}\text { SBPbrach } \\
(\mathrm{mmHg})\end{array} \\
\text {. }\end{array}$ & $\begin{array}{c}\text { DBPbrach } \\
\text { (mmHg) }\end{array}$ & $\underset{(1 / \mathrm{min})}{\mathrm{HR}}$ \\
\hline 3 & 53 & $15.9 \pm 2.3$ & $104.3 \pm 6.4$ & $14.6 \pm 1.7$ & $93.6 \pm 7.5$ & $58.9 \pm 5.9$ & $96.9 \pm 15$ & 10 & $19.1 \pm 2.5$ & $102.5 \pm 6.4$ & $18.1 \pm 0.5$ & $107.4 \pm 8.9$ & $60.9 \pm 4.7$ & $100.8 \pm 13.2$ & 1 & 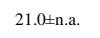 & 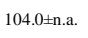 & 19.4nn.a. & $111.0 \pm$ n.a. & $65.0 \pm$ n.a. & 110.0n.a. \\
\hline 4 & 79 & $17.7 \pm 2.6$ & $109.3 \pm 7.1$ & $14.8 \pm 1.5$ & $94.9 \pm 9.3$ & $57.5 \pm 7.2$ & $92.5 \pm 12.8$ & 12 & $23.1 \pm 4.9$ & $111.7 \pm 11.5$ & $18.3 \pm 0.5$ & $111.0 \pm 9.0$ & $64.5 \pm 7.1$ & $89.8 \pm 10.9$ & 3 & $26.3 \pm 2.5$ & $115.0 \pm 5.0$ & $19.9 \pm 0.2$ & $117.7 \pm 15.2$ & $56.7 \pm 3.5$ & $84.7 \pm 11.5$ \\
\hline 5 & 137 & $20.1 \pm 2.7$ & $116.2 \pm 6.2$ & $14.9 \pm 1.5$ & $97.9 \pm 8.8$ & $59.5 \pm 6.5$ & $91.1 \pm 13.1$ & 18 & $25.5 \pm 3.1$ & $117.9 \pm 5.9$ & $18.3 \pm 0.7$ & $113.8 \pm 8.4$ & $67.1 \pm 7.3$ & $89.2 \pm 13.7$ & 10 & $32.9 \pm 5.2$ & $121.2 \pm 7.0$ & $22.3 \pm 2.3$ & $126.0 \pm 15.1$ & $64.8+7.5$ & $93.5 \pm 16.0$ \\
\hline 6 & 209 & $22.1 \pm 2.9$ & $122 \pm 5.8$ & $14.8 \pm 1.4$ & $98.5 \pm 9.6$ & $59.5 \pm 7$ & $86.4 \pm 12.4$ & 21 & $29.2 \pm 3.8$ & $125.4 \pm 7.9$ & $18.5 \pm 0.6$ & $113.0 \pm 12.0$ & $62.9 \pm 7.1$ & $83.1 \pm 10.9$ & 24 & $37.0 \pm 7.7$ & $126.5 \pm 5.3$ & $23.0 \pm 3.3$ & $120.0 \pm 12.6$ & 65.377 .7 & $85.7 \pm 14.3$ \\
\hline 7 & 169 & $24.7 \pm 3.4$ & 127.346 .2 & $15.2 \pm 1.4$ & $100.1 \pm 9.3$ & $60.1 \pm 6.7$ & $82.3 \pm 13.1$ & 33 & $33.2 \pm 3.6$ & $131.7 \pm 6.4$ & $19.1 \pm 0.8$ & $116.4 \pm 8.6$ & $67.3 \pm 5.6$ & $84.8 \pm 13.4$ & 22 & $44.8 \pm 8.9$ & $135.0 \pm 5.8$ & $24.4 \pm 3.7$ & $126.0 \pm 12.3$ & $68.7 \pm 8.1$ & $84.0 \pm 13.0$ \\
\hline 8 & 177 & $28.3 \pm 4.2$ & $133.7 \pm 6.8$ & $15.8 \pm 1.5$ & $100.8 \pm 10.3$ & $60.2 \pm 6.4$ & $79.3 \pm 12.8$ & 30 & $37.5 \pm 4.3$ & $136.9 \pm 6.8$ & $20.0 \pm 1.0$ & $116.0 \pm 9.3$ & $67.4 \pm 5.7$ & $80.8 \pm 10.4$ & 20 & $49.0 \pm 6.7$ & $139.3 \pm 8.0$ & $25.2 \pm 2.6$ & $121.8 \pm 9.9$ & $69.3 \pm 5.3$ & $80.1 \pm 10.8$ \\
\hline 9 & 201 & $31.2 \pm 5.0$ & $138.6 \pm 7.3$ & $16.2 \pm 1.7$ & $102.5 \pm 9.7$ & $61.7 \pm 7.0$ & $79.1 \pm 13.7$ & 24 & $41.5 \pm 4.0$ & $141.0 \pm 6.3$ & $20.9 \pm 1.0$ & $119.8 \pm 8.7$ & $67.2 \pm 6.4$ & $77.0 \pm 9.6$ & 28 & $56.2 \pm 10.4$ & $146.1 \pm 6.2$ & $26.2 \pm 3.6$ & $127.5 \pm 15.0$ & $72.0 \pm 7.7$ & $86.8 \pm 14.6$ \\
\hline 10 & 149 & $35.3 \pm 5.4$ & $144.2 \pm 6.7$ & $16.9 \pm 1.7$ & $102.3 \pm 9.9$ & $61.6 \pm 5.8$ & $75.1 \pm 11.5$ & 40 & $49.5 \pm 4.9$ & $149.2 \pm 6.3$ & $22.2 \pm 1.1$ & $122.4 \pm 10.1$ & $70.3 \pm 6.0$ & $80.6 \pm 13.8$ & 38 & $64.1 \pm 11.0$ & $150.9 \pm 7.0$ & $28.0 \pm 3.7$ & $128.0 \pm 13.3$ & $69.2+9.2$ & $79.0 \pm 14.7$ \\
\hline 11 & 180 & $37.5 \pm 6.6$ & $148.2 \pm 8.0$ & $17.0 \pm 1.9$ & $103.1 \pm 10.2$ & $61.6 \pm 6.2$ & $73.9 \pm 12.3$ & 55 & 53.477 .2 & $152.3 \pm 8.5$ & $22.9 \pm 1.4$ & $122.1 \pm 10.6$ & $68.9 \pm 6.4$ & $75.0 \pm 11.3$ & 32 & $71.8 \pm 10.8$ & 158.377 .8 & $28.5 \pm 2.6$ & $133.0 \pm 14.2$ & $73.9 \pm 9.9$ & $79.8 \pm 14.8$ \\
\hline 12 & 214 & $43.1 \pm 8.3$ & $155.6 \pm 9.1$ & $17.7 \pm 2.0$ & $108.1 \pm 11.4$ & 63.377 .2 & $77.1 \pm 13.7$ & 46 & $60.2 \pm 7.7$ & $160.5 \pm 8.5$ & $23.3 \pm 1.4$ & $122.5 \pm 8.6$ & $68.1 \pm 7.0$ & $75.0 \pm 12.7$ & 42 & $84.3 \pm 12.6$ & $164.4 \pm 7.5$ & $31.1 \pm 3.6$ & $134.8 \pm 11.2$ & $72.9 \pm 7.8$ & $82.3 \pm 13.2$ \\
\hline 13 & 273 & $49.7 \pm 8.7$ & 163.499 .1 & $18.5 \pm 2.0$ & $111.7 \pm 11.6$ & $63.6 \pm 6.7$ & $76.4 \pm 13.6$ & 61 & $68.9 \pm 8.2$ & $167.6 \pm 8.4$ & $24.5 \pm 1.5$ & $125.8 \pm 10.6$ & $67.7 \pm 7.1$ & $73.2 \pm 10.4$ & 64 & $88.2 \pm 13.0$ & $1699.0 \pm 7.6$ & $30.8 \pm 3.2$ & $137.5 \pm 14.7$ & $72.4 \pm 10.2$ & $79.8 \pm 13.9$ \\
\hline 14 & 403 & 56.499 .2 & $171.2 \pm 9.3$ & $19.1 \pm 1.9$ & $115.7 \pm 12.3$ & $65.6 \pm 7.8$ & $73.2 \pm 13.4$ & 104 & $75.8 \pm 9.2$ & $173.3 \pm 9.1$ & $25.1 \pm 1.3$ & $131.3 \pm 11.7$ & $70.1 \pm 7.7$ & $73.6 \pm 14.1$ & 61 & $98.4 \pm 17.1$ & $173.9 \pm 8.4$ & $32.4 \pm 4.1$ & $143.4 \pm 16.5$ & $78.9 \pm 10.1$ & $81.8 \pm 14.7$ \\
\hline 15 & 423 & $60.6 \pm 8.9$ & $175.2 \pm 7.7$ & $19.7 \pm 2.1$ & $118.3 \pm 13.9$ & $67.2 \pm 8.2$ & $70.9 \pm 13.5$ & 82 & $79.2 \pm 8.5$ & $175.8 \pm 7.3$ & $25.6 \pm 1.5$ & $132.1 \pm 12.2$ & $70.9 \pm 7.5$ & $69.9 \pm 11.8$ & 50 & $102.2 \pm 13.0$ & $174.8 \pm 6.7$ & $33.5 \pm 4.2$ & $148.4 \pm 11.9$ & $79.7 \pm 7.9$ & $77.1 \pm 14.5$ \\
\hline 16 & 395 & $63.7 \pm 9.5$ & $177 \pm 7.3$ & $20.3 \pm 2.3$ & $122.3 \pm 13.8$ & $68.8 \pm 8.1$ & $72.1 \pm 14.7$ & 65 & 82.448 .1 & $178.1 \pm 7.5$ & $25.9 \pm 1.2$ & $134.1 \pm 12.2$ & $73.4+8.4$ & $70.4 \pm 12.7$ & 48 & $105.3 \pm 13.5$ & 177.447 .2 & $33.4 \pm 3.4$ & $146.1 \pm 13.2$ & $80.5 \pm 9.1$ & $76.8 \pm 11.8$ \\
\hline 17 & 372 & $66.1 \pm 9.2$ & $178.4+7.2$ & $20.7 \pm 2.2$ & $123.6 \pm 15.1$ & $68.8 \pm 8.2$ & $70.2 \pm 13.2$ & 54 & $86.0 \pm 9.4$ & $179.5 \pm 8.1$ & $26.6 \pm 1.4$ & $137.9 \pm 12.0$ & $73.5 \pm 8.4$ & $71.7 \pm 11.4$ & 38 & $107.6 \pm 12.4$ & 179.377 .5 & $33.4 \pm 3.4$ & $148.3 \pm 13.1$ & $81.5 \pm 8.7$ & $76.5 \pm 14.4$ \\
\hline 18 & 124 & $68.2+8.1$ & $179.5+6.8$ & $21.1 \pm 2.0$ & $122.8 \pm 12.5$ & $65.3 \pm 7.4$ & $71 \pm 13.6$ & 21 & $85.1 \pm 10.6$ & $178.3 \pm 8.5$ & $26.7 \pm 1.4$ & $143.2 \pm 13.3$ & $74.6 \pm 8.4$ & $77.0 \pm 16.5$ & 4 & $100.0 \pm 13.7$ & $175.3 \pm 6.6$ & $32.4 \pm 2.3$ & $143.3 \pm 17.5$ & $80.8 \pm 4.5$ & $73.8 \pm 3.8$ \\
\hline
\end{tabular}

Data are presented as mean $\pm \mathrm{SD}$. BMI, body mass index; SBP, systolic blood pressure; DBP, diastolic blood pressure; HR, heart rate; NS, non-significant difference; n.a., not applicable 
Supplementary Table 1A/b Comparison of normal weight, overweight and obese boys' characteristics (Student's t-test)

age
(ys)

\begin{tabular}{|c|c|c|c|c|c|c|c|c|c|c|c|c|c|c|c|c|c|c|}
\hline & weight & height & BMI & SBP & DBP & HR & weight & height & BMI & SBP & DBP & HR & weight & height & BMI & SBP & DBP & HR \\
\hline 3 & $\mathrm{p}<0.0003$ & NS & $\mathrm{p}<0.0001$ & $\mathrm{p}<0.0001$ & NS & NS & n.a. & n.a. & n.a. & n.a. & n.a. & n.a. & n.a. & n.a. & n.a. & n.a. & n.a. & n.a. \\
\hline 4 & $\mathrm{p}<0.0001$ & NS & $\mathrm{p}<0.0001$ & $\mathrm{p}<0.0001$ & $\mathrm{p}<0.003$ & NS & $\mathrm{p}<0.0001$ & NS & $\mathrm{p}<0.0001$ & $\mathrm{p}<0.0002$ & NS & NS & NS & NS & $\mathrm{p}<0.0001$ & NS & NS & NS \\
\hline 5 & $\mathrm{p}<0.0001$ & NS & $\mathrm{p}<0.0001$ & $\mathrm{p}<0.0001$ & $\mathrm{p}<0.0001$ & NS & $\mathrm{p}<0.0001$ & $\mathrm{p}<0.02$ & $\mathrm{p}<0.0001$ & $\mathrm{p}<0.0001$ & $\mathrm{p}<0.02$ & NS & $\mathrm{p}<0.0001$ & NS & $\mathrm{p}<0.0001$ & $\mathrm{p}<0.02$ & NS & NS \\
\hline 6 & $\mathrm{p}<0.0001$ & $\mathrm{p}<0.02$ & $\mathrm{p}<0.0001$ & $\mathrm{p}<0.0001$ & $\mathrm{p}<0.04$ & NS & $\mathrm{p}<0.0001$ & $\mathrm{p}<0.0005$ & $\mathrm{p}<0.0001$ & $\mathrm{p}<0.0001$ & $\mathrm{p}<0.002$ & NS & $\mathrm{p}<0.0002$ & NS & $\mathrm{p}<0.0001$ & NS & NS & NS \\
\hline 7 & $\mathrm{p}<0.0001$ & $\mathrm{p}<0.0003$ & $\mathrm{p}<0.0001$ & $\mathrm{p}<0.0001$ & $\mathrm{p}<0.0001$ & NS & $\mathrm{p}<0.0001$ & $\mathrm{p}<0.0001$ & $\mathrm{p}<0.0001$ & $\mathrm{p}<0.0001$ & $\mathrm{p}<0.0001$ & NS & $\mathrm{p}<0.0001$ & NS & $\mathrm{p}<0.0001$ & $\mathrm{p}<0.002$ & NS & NS \\
\hline 8 & $\mathrm{p}<0.0001$ & $\mathrm{p}<0.02$ & $\mathrm{p}<0.0001$ & $\mathrm{p}<0.0001$ & $\mathrm{p}<0.0001$ & NS & $\mathrm{p}<0.0001$ & $\mathrm{p}<0.0008$ & $\mathrm{p}<0.0001$ & $\mathrm{p}<0.0001$ & $\mathrm{p}<0.0001$ & NS & $\mathrm{p}<0.0001$ & NS & $\mathrm{p}<0.0001$ & $\mathrm{p}<0.05$ & NS & NS \\
\hline 9 & $\mathrm{p}<0.0001$ & NS & $\mathrm{p}<0.0001$ & $\mathrm{p}<0.0001$ & $\mathrm{p}<0.0003$ & NS & $\mathrm{p}<0.0001$ & $\mathrm{p}<0.0001$ & $\mathrm{p}<0.0001$ & $\mathrm{p}<0.0001$ & $\mathrm{p}<0.0001$ & $p<0.007$ & $\mathrm{p}<0.0001$ & $\mathrm{p}<0.005$ & $\mathrm{p}<0.0001$ & $\mathrm{p}<0.04$ & $\mathrm{p}<0.02$ & $\mathrm{p}<0.008$ \\
\hline 10 & $p<0.0001$ & $\mathrm{p}<0.0001$ & $\mathrm{p}<0.0001$ & $\mathrm{p}<0.0001$ & $\mathrm{p}<0.0001$ & $\mathrm{p}<0.02$ & $\mathrm{p}<0.0001$ & $\mathrm{p}<0.0001$ & $\mathrm{p}<0.0001$ & $\mathrm{p}<0.0001$ & $\mathrm{p}<0.0001$ & NS & $\mathrm{p}<0.0001$ & NS & $\mathrm{p}<0.0001$ & $\mathrm{p}<0.05$ & NS & NS \\
\hline 11 & $\mathrm{p}<0.0001$ & $\mathrm{p}<0.002$ & $\mathrm{p}<0.0001$ & $\mathrm{p}<0.0001$ & $\mathrm{p}<0.0001$ & NS & $\mathrm{p}<0.0001$ & $\mathrm{p}<0.0001$ & $\mathrm{p}<0.0001$ & $\mathrm{p}<0.0001$ & $\mathrm{p}<0.0001$ & $\mathrm{p}<0.02$ & $\mathrm{p}<0.0001$ & $\mathrm{p}<0.002$ & $\mathrm{p}<0.0001$ & $\mathrm{p}<0.0002$ & $\mathrm{p}<0.006$ & NS \\
\hline 12 & $\mathrm{p}<0.0001$ & $\mathrm{p}<0.001$ & $\mathrm{p}<0.0001$ & $\mathrm{p}<0.0001$ & $\mathrm{p}<0.0001$ & NS & $\mathrm{p}<0.0001$ & $\mathrm{p}<0.0001$ & $\mathrm{p}<0.0001$ & $\mathrm{p}<0.0001$ & $\mathrm{p}<0.0001$ & $\mathrm{p}<0.03$ & $\mathrm{p}<0.0001$ & $\mathrm{p}<0.03$ & $\mathrm{p}<0.0001$ & $\mathrm{p}<0.0001$ & $\mathrm{p}<0.003$ & $\mathrm{p}<0.02$ \\
\hline 13 & $\mathrm{p}<0.0001$ & $\mathrm{p}<0.002$ & $\mathrm{p}<0.0001$ & $\mathrm{p}<0.0001$ & $\mathrm{p}<0.0001$ & NS & $\mathrm{p}<0.0001$ & $\mathrm{p}<0.0001$ & $\mathrm{p}<0.0001$ & $\mathrm{p}<0.0001$ & $\mathrm{p}<0.0001$ & NS & $\mathrm{p}<0.0001$ & NS & $\mathrm{p}<0.0001$ & $\mathrm{p}<0.0001$ & $\mathrm{p}<0.004$ & $\mathrm{p}<0.004$ \\
\hline 14 & $\mathrm{p}<0.0001$ & $\mathrm{p}<0.04$ & $\mathrm{p}<0.0001$ & $\mathrm{p}<0.0001$ & $\mathrm{p}<0.0001$ & NS & $\mathrm{p}<0.0001$ & $\mathrm{p}<0.04$ & $\mathrm{p}<0.0001$ & $\mathrm{p}<0.0001$ & $\mathrm{p}<0.0001$ & $\mathrm{p}<0.0001$ & $\mathrm{p}<0.0001$ & NS & $\mathrm{p}<0.0001$ & $p<0.0001$ & $p<0.0001$ & $\mathrm{p}<0.0005$ \\
\hline 15 & $\mathrm{p}<0.0001$ & NS & $\mathrm{p}<0.0001$ & $\mathrm{p}<0.0001$ & $\mathrm{p}<0.0003$ & NS & $\mathrm{p}<0.0001$ & NS & $\mathrm{p}<0.0001$ & $\mathrm{p}<0.0001$ & $\mathrm{p}<0.0001$ & $\mathrm{p}<0.003$ & $\mathrm{p}<0.0001$ & NS & $\mathrm{p}<0.0001$ & $\mathrm{p}<0.0001$ & $\mathrm{p}<0.0001$ & $\mathrm{p}<0.003$ \\
\hline 16 & $\mathrm{p}<0.0001$ & NS & $\mathrm{p}<0.0001$ & $\mathrm{p}<0.0001$ & $\mathrm{p}<0.0001$ & NS & $\mathrm{p}<0.0001$ & NS & $\mathrm{p}<0.0001$ & $\mathrm{p}<0.0001$ & $\mathrm{p}<0.0001$ & $\mathrm{p}<0.04$ & $\mathrm{p}<0.0001$ & NS & $\mathrm{p}<0.0001$ & $\mathrm{p}<0.0001$ & $\mathrm{p}<0.0001$ & $\mathrm{p}<0.009$ \\
\hline 17 & $\mathrm{p}<0.0001$ & NS & $\mathrm{p}<0.0001$ & $\mathrm{p}<0.0001$ & $\mathrm{p}<0.0001$ & NS & $\mathrm{p}<0.0001$ & NS & $\mathrm{p}<0.0001$ & $\mathrm{p}<0.0001$ & $\mathrm{p}<0.0001$ & $\mathrm{p}<0.007$ & $\mathrm{p}<0.0001$ & NS & $\mathrm{p}<0.0001$ & $\mathrm{p}<0.0002$ & $\mathrm{p}<0.0001$ & NS \\
\hline 1 & $\mathrm{p}<0.0001$ & NS & $\mathrm{p}<0.0001$ & $\mathrm{p}<0.0001$ & $\mathrm{p}<0.0001$ & NS & $\mathrm{p}<0.0001$ & NS & $\mathrm{p}<0.0001$ & $\mathrm{p}<0.002$ & $\mathrm{p}<0.0001$ & NS & $\mathrm{p}<0.03$ & NS & $\mathrm{p}<0.0001$ & NS & NS & NS \\
\hline
\end{tabular}

Data are presented as mean \pm SD. BMI, body mass index; SBP, systolic blood pressure; DBP, diastolic blood pressure; HR, heart rate; NS, non-significant difference; n.a., not applicable 
Supplementary Table 1B/a Characteristics of normal weight, overweight and obese girls

\begin{tabular}{|c|c|c|c|c|c|c|c|c|c|c|c|c|c|c|c|c|c|c|c|c|c|}
\hline \multirow[b]{2}{*}{ ys) } & \multicolumn{7}{|c|}{ normal weight } & \multicolumn{8}{|c|}{ overweight } & \multicolumn{6}{|c|}{ obese } \\
\hline & $\mathbf{n}$ & $\begin{array}{c}\text { weight } \\
(\mathrm{kg})\end{array}$ & $\begin{array}{l}\text { height } \\
(\mathrm{cm})\end{array}$ & $\underset{\left(\mathrm{kg} / \mathrm{m}^{2}\right)}{\text { BMI }}$ & $\underset{(\mathrm{mmHg})}{\mathbf{S B P}}$ & $\underset{(\mathrm{mmHg})}{\mathbf{D B P}}$ & $\underset{(1 / \mathrm{min})}{\mathbf{H R}}$ & $\mathbf{n}$ & $\begin{array}{c}\text { weight } \\
(\mathrm{kg})\end{array}$ & $\begin{array}{l}\text { height } \\
(\mathrm{cm})\end{array}$ & $\begin{array}{c}\text { BMI } \\
\left(\mathrm{kg} / \mathrm{m}^{2}\right)\end{array}$ & $\underset{(\mathrm{mmHg})}{\mathbf{S B P}}$ & $\underset{(\mathrm{mmHg})}{\mathbf{D B P}}$ & $\underset{(1 / \mathrm{min})}{\mathbf{H R}}$ & $\mathbf{n}$ & $\begin{array}{c}\text { weight } \\
(\mathrm{kg})\end{array}$ & $\begin{array}{l}\text { height } \\
(\mathrm{cm})\end{array}$ & $\underset{\left(\mathrm{kg} / \mathrm{m}^{2}\right)}{\text { BMI }}$ & $\underset{(\mathrm{mmHg})}{\mathbf{S B P}}$ & $\underset{(\mathrm{mmHg})}{\text { DBP }}$ & $\underset{(1 / \mathrm{min})}{\mathbf{H R}}$ \\
\hline 3 & 38 & $15.8 \pm 2.4$ & $102.7 \pm 6.1$ & $14.9 \pm 1.2$ & $94.1 \pm 7.1$ & $57.1 \pm 8.1$ & $98.7 \pm 14.0$ & 6 & $18.7 \pm 3.2$ & $100.5 \pm 7.9$ & $18.4 \pm 0.6$ & $112.3 \pm 6.7$ & $62.3 \pm 3.7$ & $104.7 \pm 8.8$ & 4 & $22.8 \pm 2.9$ & $104.0 \pm 5.5$ & $21.0 \pm 1.0$ & $122.3 \pm 6.1$ & $70.8 \pm 3.1$ & $92.3 \pm 9.4$ \\
\hline 4 & 70 & $17.2 \pm 2.5$ & $108.8 \pm 6.5$ & $14.5 \pm 1.7$ & $97.0 \pm 9.5$ & $57.7 \pm 6.4$ & $93.5 \pm 11.2$ & 12 & $21.1 \pm 3.5$ & $108.1 \pm 8.4$ & $17.9 \pm 0.4$ & $110.9 \pm 9.0$ & $62.5 \pm 6.2$ & $97.7 \pm 17.0$ & 12 & $29.8 \pm 4.0$ & $113.5 \pm 6.4$ & $23.1 \pm 2.5$ & $119.9 \pm 6.6$ & $62.3 \pm 5.8$ & $97.8 \pm 10.4$ \\
\hline 5 & 89 & $18.7 \pm 2.9$ & $114.4 \pm 6.9$ & $14.3 \pm 1.5$ & $97.6 \pm 10.8$ & $58.8 \pm 7.6$ & $93.9 \pm 12.0$ & 12 & $27.1 \pm 3.1$ & $122.3 \pm 6.6$ & $18.1 \pm 0.7$ & $119.3 \pm 14.8$ & $67.6 \pm 9.6$ & $91.8 \pm 15.5$ & 8 & $30.4 \pm 5.7$ & $118.6 \pm 8.0$ & $21.4 \pm 1.9$ & $117.4 \pm 12.0$ & $65.0 \pm 6.3$ & $88.8 \pm 11.1$ \\
\hline 6 & 145 & $21.5 \pm 3.2$ & $121.5 \pm 6.6$ & $14.5 \pm 1.5$ & $99.0 \pm 10.3$ & $59.4 \pm 6.9$ & $88.7 \pm 14.2$ & 24 & $28.6 \pm 4.4$ & $124.0 \pm 8.6$ & $18.5 \pm 0.8$ & $112.8 \pm 10.5$ & $64.8 \pm 7.7$ & $85.0 \pm 10.9$ & 10 & $32.8 \pm 5.2$ & $120.3 \pm 4.9$ & $22.5 \pm 2.1$ & $117.4 \pm 14.5$ & $66.4 \pm 9.6$ & $90.6 \pm 7.4$ \\
\hline 7 & 128 & $23.8 \pm 4.2$ & $126.8 \pm 7.0$ & $14.7 \pm 1.8$ & $100.2 \pm 10.5$ & $60.5 \pm 6.9$ & $86.6 \pm 12.8$ & 17 & $32.4 \pm 2.8$ & $131.2 \pm 4.6$ & $18.8 \pm 0.8$ & $115.4 \pm 8.4$ & $64.1 \pm 5.6$ & $85.4 \pm 9.0$ & 11 & $40.6 \pm 6.7$ & $131.5 \pm 4.2$ & $23.4 \pm 2.5$ & $125.6 \pm 17.0$ & $70.1 \pm 8.2$ & $88.3 \pm 16.4$ \\
\hline 8 & 123 & $27.2 \pm 4.6$ & $132.9 \pm 6.5$ & $15.3 \pm 1.7$ & $101.8 \pm 10.3$ & $60.9 \pm 6.2$ & $84.5 \pm 12.4$ & 23 & $36.0 \pm 5.0$ & $134.2 \pm 6.7$ & $19.9 \pm 1.2$ & $118.0 \pm 10.0$ & $68.0 \pm 7.0$ & $81.7 \pm 13.7$ & 17 & $48.5 \pm 4.4$ & $141.4 \pm 3.9$ & $24.2 \pm 1.6$ & $124.5 \pm 10.7$ & $70.1 \pm 6.2$ & $86.3 \pm 9.1$ \\
\hline 9 & 142 & $.8 \pm 5.2$ & $7.6 \pm 7.5$ & $15.7 \pm 1.8$ & $2.8 \pm 10.3$ & $1.3 \pm 6.4$ & $.0 \pm 12.4$ & 35 & $41.2 \pm 5.5$ & $39.7 \pm 7.8$ & $21.0 \pm 1.0$ & $18.5 \pm 11.9$ & $66.8 \pm 7.1$ & $83.4 \pm 15.3$ & 17 & $55.3 \pm 7.3$ & $146.0 \pm 7.8$ & $25.9 \pm 2.0$ & $125.9 \pm 14.0$ & $68.6 \pm 9.5$ & $82.0 \pm 12.2$ \\
\hline 10 & 139 & $34.0 \pm 5.9$ & $143.7 \pm 7.3$ & $16.4 \pm 1.9$ & $105.6 \pm 10.9$ & $62.3 \pm 6.5$ & $83.5 \pm 13.8$ & 25 & $47.5 \pm 4.8$ & $147.7 \pm 6.7$ & $21.7 \pm 0.9$ & $21.5 \pm 12.6$ & $69.4 \pm 8.3$ & $87.4 \pm 15.7$ & 21 & $69.5 \pm 10.5$ & $154.3 \pm 8.6$ & $29.1 \pm 3.1$ & $139.2 \pm 14.9$ & $73.3 \pm 6.4$ & $94.4 \pm 13.6$ \\
\hline 11 & 138 & $38.4 \pm 7.2$ & $149.2 \pm 9.3$ & $17.1 \pm 2.0$ & $105.2 \pm 10.1$ & $63.1 \pm 7.0$ & $80.4 \pm 13.3$ & 28 & $56.5 \pm 7.7$ & $155.8 \pm 8.7$ & $23.2 \pm 1.4$ & $124.0 \pm 11.0$ & $66.3 \pm 8.7$ & $83.0 \pm 15.0$ & 24 & $72.5 \pm 10.3$ & $157.3 \pm 8.1$ & $29.2 \pm 2.3$ & $128.6 \pm 13.3$ & $70.8 \pm 9.9$ & $85.5 \pm 13.1$ \\
\hline 12 & 200 & $43.4 \pm 7.3$ & $155.7 \pm 7.5$ & $17.8 \pm 2.0$ & $109.7 \pm 12.2$ & $64.4 \pm 7.5$ & $82.1 \pm 14.5$ & 43 & $63.2 \pm 7.0$ & $160.7 \pm 7.1$ & $24.4 \pm 1.7$ & $127.0 \pm 12.3$ & $70.4 \pm 7.7$ & $82.5 \pm 12.1$ & 23 & $79.5 \pm 10.8$ & $161.0 \pm 6.7$ & $30.8 \pm 4.8$ & $134.7 \pm 16.0$ & $74.9 \pm 10$ & $83.7 \pm 14.6$ \\
\hline 13 & 306 & $49.4 \pm 6.9$ & $161.6 \pm 6.9$ & $18.9 \pm 2.0$ & $111.5 \pm 12.6$ & $64.8 \pm 7.4$ & $79.3 \pm 14.1$ & 61 & $65.4 \pm 7.5$ & $161.9 \pm 9.1$ & $24.9 \pm 1.5$ & $129.2 \pm 12.6$ & $71.5 \pm 7.9$ & $81.0 \pm 14.3$ & 26 & $87.8 \pm 13.8$ & $162.9 \pm 8.5$ & $33.0 \pm 4.2$ & $140.4 \pm 13.6$ & $76.7 \pm 9.9$ & $84.1 \pm 13.5$ \\
\hline 14 & 390 & $52.3 \pm 7.4$ & $164.3 \pm 6.6$ & $19.3 \pm 2.1$ & $111.5 \pm 11.9$ & $65.3 \pm 7.1$ & $76.6 \pm 14.1$ & 52 & $69.1 \pm 7.5$ & $163.2 \pm 7.2$ & $25.9 \pm 1.5$ & $128.1 \pm 12.0$ & $71.6 \pm 7.5$ & $78.7 \pm 13.8$ & 24 & $87.4 \pm 12.2$ & $163.8 \pm 5.6$ & $32.5 \pm 3.5$ & $141.6 \pm 15.2$ & $79.3 \pm 9.2$ & $86.4 \pm 12.5$ \\
\hline 15 & 394 & $53.9 \pm 7.5$ & $164.8 \pm 6.7$ & $19.8 \pm 2.2$ & $110.8 \pm 11.8$ & $66.2 \pm 7.3$ & $76.1 \pm 13.8$ & 58 & $70.3 \pm 6.3$ & $164.3 \pm 6.5$ & $26.0 \pm 1.3$ & $125.1 \pm 10.6$ & $72.0 \pm 6.5$ & $76.8 \pm 12.7$ & 34 & $96.8 \pm 13.5$ & $168.5 \pm 7.1$ & $34.1 \pm 4.6$ & $142.8 \pm 15.4$ & $79.4 \pm 7.4$ & $83.7 \pm 13.4$ \\
\hline 16 & 361 & $54.8 \pm 7.1$ & $165.4 \pm 6.6$ & $20 \pm 2.2$ & $112.7 \pm 11.3$ & $68.0 \pm 7.3$ & $76.6 \pm 13.3$ & 51 & $72.2 \pm 7.5$ & $165.4 \pm 7.2$ & $26.3 \pm 1.3$ & $130.2 \pm 12.9$ & $74.0 \pm 8.2$ & $78.2 \pm 13.4$ & 28 & $92.4 \pm 10.9$ & $165.6 \pm 5.6$ & $33.7 \pm 3.4$ & $137.6 \pm 11.2$ & $78.5 \pm 5.2$ & $79.6 \pm 11.7$ \\
\hline 17 & 326 & $55.6 \pm 7.2$ & $165.9 \pm 6.2$ & $20.2 \pm 2.1$ & $113.5 \pm 12.1$ & $67.2 \pm 7.5$ & $76.8 \pm 12.6$ & 49 & $75.5 \pm 8.6$ & $166.6 \pm 7.7$ & $27.1 \pm 1.5$ & $131.0 \pm 14.1$ & $73.6 \pm 8.8$ & $73.5 \pm 11.5$ & 13 & $95.6 \pm 12.9$ & $161.1 \pm 5.9$ & $36.8 \pm 4.0$ & $143.9 \pm 14.5$ & $76.2 \pm 9.2$ & $76.8 \pm 9.2$ \\
\hline 18 & 135 & $56.6 \pm 6.4$ & $166.0 \pm 6.7$ & $20.6 \pm 2.0$ & $116.6 \pm 13.6$ & $67.8 \pm 7.1$ & $79.5 \pm 13.0$ & 10 & $76.6 \pm 7.0$ & $166.3 \pm 7.6$ & $27.7 \pm 1.6$ & $125.9 \pm 10.8$ & $71.5 \pm 3.7$ & $86.5 \pm 8.5$ & & $102.0 \pm 9.8$ & $169.0 \pm 7.1$ & $35.7 \pm 3.6$ & $133.7 \pm 15.0$ & $62.0 \pm 9.5$ & $77.7 \pm 1.2$ \\
\hline
\end{tabular}

Data are presented as mean \pm SD. BMI, body mass index; SBP, systolic blood pressure; DBP, diastolic blood pressure; HR, heart rate; NS, non-significant difference; n.a., not applicable 
Supplementary Table 1B/b Comparison of normal weight, overweight and obese girls' characteristics (Student's t-test)

\begin{tabular}{|c|c|c|c|c|c|c|c|c|c|c|c|c|c|c|c|c|c|c|}
\hline \multirow{2}{*}{$\begin{array}{l}\text { age } \\
\text { (ys) }\end{array}$} & \multicolumn{6}{|c|}{ overweight vs normal weight } & \multicolumn{6}{|c|}{ obese vs normal weight } & \multicolumn{6}{|c|}{ overweight vs obese } \\
\hline & weight & height & BMI & SBP & DBP & HR & weight & height & BMI & SBP & DBP & HR & weight & height & BMI & SBP & DBP & HR \\
\hline 3 & $\mathrm{p}<0.02$ & NS & $\mathrm{p}<0.0001$ & $\mathrm{p}<0.0001$ & NS & NS & NS & $\mathrm{p}<0.0001$ & $\mathrm{p}<0.0001$ & $\mathrm{p}<0.0001$ & $\mathrm{p}<0.002$ & NS & NS & $\mathrm{p}<0.0007$ & $\mathrm{p}<0.0001$ & $\mathrm{p}<0.05$ & $\mathrm{p}<0.006$ & NS \\
\hline 4 & $\mathrm{p}<0.0001$ & NS & $\mathrm{p}<0.0001$ & $\mathrm{p}<0.0001$ & $\mathrm{p}<0.02$ & NS & $\mathrm{p}<0.0001$ & $\mathrm{p}<0.003$ & $\mathrm{p}<0.0001$ & $\mathrm{p}<0.0001$ & $\mathrm{p}<0.03$ & NS & $\mathrm{p}<0.0001$ & NS & $\mathrm{p}<0.0001$ & $\mathrm{p}<0.02$ & NS & NS \\
\hline 5 & $\mathrm{p}<0.0001$ & $\mathrm{p}<0.0004$ & $\mathrm{p}<0.0001$ & $\mathrm{p}<0.0001$ & $\mathrm{p}<0.0005$ & NS & $\mathrm{p}<0.0001$ & NS & $\mathrm{p}<0.0001$ & $\mathrm{p}<0.0001$ & $\mathrm{p}<0.03$ & NS & NS & NS & $\mathrm{p}<0.0001$ & NS & NS & NS \\
\hline 6 & $\mathrm{p}<0.0001$ & NS & $\mathrm{p}<0.0001$ & $\mathrm{p}<0.0001$ & $\mathrm{p}<0.0005$ & NS & $\mathrm{p}<0.0001$ & NS & $\mathrm{p}<0.0001$ & $\mathrm{p}<0.0001$ & $\mathrm{p}<0.04$ & NS & $\mathrm{p}<0.03$ & NS & $\mathrm{p}<0.0001$ & NS & NS & NS \\
\hline 7 & $\mathrm{p}<0.0001$ & $\mathrm{p}<0.02$ & $\mathrm{p}<0.0001$ & $\mathrm{p}<0.0001$ & $\mathrm{p}<0.05$ & NS & $\mathrm{p}<0.0001$ & $\mathrm{p}<0.03$ & $\mathrm{p}<0.0001$ & $\mathrm{p}<0.0001$ & $\mathrm{p}<0.0001$ & NS & $\mathrm{p}<0.0002$ & NS & $\mathrm{p}<0.0001$ & $\mathrm{p}<0.05$ & $\mathrm{p}<0.03$ & NS \\
\hline 8 & $\mathrm{p}<0.0001$ & NS & $\mathrm{p}<0.0001$ & $\mathrm{p}<0.0001$ & $\mathrm{p}<0.0001$ & NS & $\mathrm{p}<0.0001$ & $\mathrm{p}<0.0001$ & $\mathrm{p}<0.0001$ & $\mathrm{p}<0.0001$ & $\mathrm{p}<0.0001$ & NS & $\mathrm{p}<0.0001$ & $\mathrm{p}<0.0003$ & $\mathrm{p}<0.0001$ & NS & NS & NS \\
\hline 9 & $\mathrm{p}<0.0001$ & NS & $\mathrm{p}<0.0001$ & $\mathrm{p}<0.0001$ & $\mathrm{p}<0.0001$ & NS & $\mathrm{p}<0.0001$ & $\mathrm{p}<0.0001$ & $\mathrm{p}<0.0001$ & $\mathrm{p}<0.0001$ & $\mathrm{p}<0.0001$ & NS & $\mathrm{p}<0.0001$ & $\mathrm{p}<0.009$ & $\mathrm{p}<0.0001$ & $\mathrm{p}<0.05$ & NS & NS \\
\hline 10 & $\mathrm{p}<0.0001$ & $\mathrm{p}<0.02$ & $\mathrm{p}<0.0001$ & $\mathrm{p}<0.0001$ & $\mathrm{p}<0.0001$ & NS & $\mathrm{p}<0.0001$ & $\mathrm{p}<0.0001$ & $\mathrm{p}<0.0001$ & $\mathrm{p}<0.0001$ & $\mathrm{p}<0.0001$ & $\mathrm{p}<0.0009$ & $\mathrm{p}<0.0001$ & $\mathrm{p}<0.005$ & $\mathrm{p}<0.0001$ & $\mathrm{p}<0.0001$ & NS & NS \\
\hline 11 & $\mathrm{p}<0.0001$ & $\mathrm{p}<0.0006$ & $\mathrm{p}<0.0001$ & $\mathrm{p}<0.0001$ & $\mathrm{p}<0.04$ & NS & $\mathrm{p}<0.0001$ & $\mathrm{p}<0.0001$ & $\mathrm{p}<0.0001$ & $\mathrm{p}<0.0001$ & $\mathrm{p}<0.0001$ & NS & $\mathrm{p}<0.0001$ & NS & $\mathrm{p}<0.0001$ & NS & NS & NS \\
\hline 12 & $\mathrm{p}<0.0001$ & $\mathrm{p}<0.0001$ & $\mathrm{p}<0.0001$ & $\mathrm{p}<0.0001$ & $\mathrm{p}<0.0001$ & NS & $\mathrm{p}<0.0001$ & $\mathrm{p}<0.002$ & $\mathrm{p}<0.0001$ & $\mathrm{p}<0.0001$ & $\mathrm{p}<0.0001$ & NS & $\mathrm{p}<0.0001$ & NS & $p<0.0001$ & $\mathrm{p}<0.04$ & $\mathrm{p}<0.05$ & NS \\
\hline 13 & $\mathrm{p}<0.0001$ & NS & $\mathrm{p}<0.0001$ & $\mathrm{p}<0.0001$ & $\mathrm{p}<0.0001$ & NS & $\mathrm{p}<0.0001$ & NS & $\mathrm{p}<0.0001$ & $\mathrm{p}<0.0001$ & $\mathrm{p}<0.0001$ & NS & $\mathrm{p}<0.0001$ & NS & $\mathrm{p}<0.0001$ & $\mathrm{p}<0.0004$ & $\mathrm{p}<0.02$ & NS \\
\hline 14 & $\mathrm{p}<0.0001$ & NS & $\mathrm{p}<0.0001$ & $\mathrm{p}<0.0001$ & $\mathrm{p}<0.0001$ & NS & $\mathrm{p}<0.0001$ & NS & $\mathrm{p}<0.0001$ & $\mathrm{p}<0.0001$ & $\mathrm{p}<0.0001$ & $p<0.001$ & $\mathrm{p}<0.0001$ & NS & $p<0.0001$ & $\mathrm{p}<0.0001$ & $\mathrm{p}<0.0003$ & $p<0.03$ \\
\hline 15 & $\mathrm{p}<0.0001$ & NS & $\mathrm{p}<0.0001$ & $\mathrm{p}<0.0001$ & $\mathrm{p}<0.0001$ & NS & $\mathrm{p}<0.0001$ & $\mathrm{p}<0.003$ & $\mathrm{p}<0.0001$ & $p<0.0001$ & $\mathrm{p}<0.0001$ & $\mathrm{p}<0.003$ & $\mathrm{p}<0.0001$ & $\mathrm{p}<0.005$ & $p<0.0001$ & $\mathrm{p}<0.0001$ & $\mathrm{p}<0.0001$ & $\mathrm{p}<0.02$ \\
\hline 16 & $\mathrm{p}<0.0001$ & NS & $\mathrm{p}<0.0001$ & $\mathrm{p}<0.0001$ & $\mathrm{p}<0.0001$ & NS & $\mathrm{p}<0.0001$ & NS & $\mathrm{p}<0.0001$ & $\mathrm{p}<0.0001$ & $\mathrm{p}<0.0001$ & NS & $\mathrm{p}<0.0001$ & NS & $\mathrm{p}<0.0001$ & $\mathrm{p}<0.02$ & $\mathrm{p}<0.01$ & NS \\
\hline 17 & $\mathrm{p}<0.0001$ & NS & $\mathrm{p}<0.0001$ & $\mathrm{p}<0.0001$ & $\mathrm{p}<0.0001$ & NS & $\mathrm{p}<0.0001$ & $\mathrm{p}<0.006$ & $\mathrm{p}<0.0001$ & $\mathrm{p}<0.0001$ & $p<0.0001$ & NS & $\mathrm{p}<0.0001$ & $\mathrm{p}<0.02$ & $\mathrm{p}<0.0001$ & $\mathrm{p}<0.005$ & NS & NS \\
\hline 18 & $\mathrm{p}<0.0001$ & NS & $\mathrm{p}<0.0001$ & $p<0.04$ & NS & NS & $\mathrm{p}<0.0001$ & NS & $\mathrm{p}<0.0001$ & $\mathrm{p}<0.04$ & NS & $p<0.005$ & $\mathrm{p}<0.0001$ & NS & $\mathrm{p}<0.0001$ & NS & $\mathrm{p}<0.02$ & $p<0.00$ \\
\hline
\end{tabular}

Data are presented as mean \pm SD. BMI, body mass index; SBP, systolic blood pressure; DBP, diastolic blood pressure; HR, heart rate; NS, non-significant difference; n.a., not applicable 
Supplementary Table 2A Distribution of blood pressure by sex, age

\begin{tabular}{|c|c|c|c|c|c|c|c|c|c|c|c|c|c|c|c|c|}
\hline & \multicolumn{8}{|c|}{ normal weight boys } & \multicolumn{8}{|c|}{ normal weight girls } \\
\hline & \multicolumn{3}{|c|}{$\begin{array}{c}\text { based on first } \\
\text { BP measurement }\end{array}$} & \multicolumn{5}{|c|}{ based on ABPM } & \multicolumn{4}{|c|}{$\begin{array}{c}\text { based on first } \\
\text { BP measurement }\end{array}$} & \multicolumn{4}{|c|}{ based on ABPM } \\
\hline & & $\mathbf{N}$ & $\mathbf{E}$ & $\mathbf{H}$ & $\begin{array}{c}\text { examination } \\
\text { proposed by GP / }\end{array}$ & $\mathbf{N}$ & $\mathbf{E}$ & $\mathbf{H}$ & & $\mathbf{N}$ & $\mathbf{E}$ & $\mathbf{H}$ & $\begin{array}{c}\text { examination } \\
\text { proposed by GP / }\end{array}$ & $\mathbf{N}$ & $\mathbf{E}$ & $\mathbf{H}$ \\
\hline age (ys) & $\mathbf{n}$ & $<90$ & $90-95$ & $95 \leq$ & $\mathrm{SP}$ & $<90$ & $90-95$ & $95 \leq$ & $\mathbf{n}$ & $<90$ & $90-95$ & $95 \leq$ & $\mathbf{S P}$ & $<90$ & $90-95$ & $95 \leq$ \\
\hline 3 & 53 & 50 & 1 & 2 & 0 & 0 & $\mathbf{0}$ & $\mathbf{0}$ & 38 & 37 & 0 & 1 & 0 & 0 & $\mathbf{0}$ & $\mathbf{0}$ \\
\hline 4 & 79 & 71 & 6 & 2 & 0 & 0 & $\mathbf{0}$ & $\mathbf{0}$ & 70 & 62 & 5 & 3 & 0 & 0 & $\mathbf{0}$ & $\mathbf{0}$ \\
\hline 5 & 137 & 119 & 8 & 10 & 0 & 0 & $\mathbf{0}$ & $\mathbf{0}$ & 89 & 80 & 8 & 1 & 0 & 0 & $\mathbf{0}$ & $\mathbf{0}$ \\
\hline 6 & 209 & 190 & 8 & 11 & 0 & 0 & $\mathbf{0}$ & $\mathbf{0}$ & 145 & 140 & 2 & 3 & 0 & 0 & $\mathbf{0}$ & $\mathbf{0}$ \\
\hline 7 & 169 & 157 & 9 & 3 & 1 & 1 & 0 & 0 & 128 & 119 & 7 & 2 & 0 & 0 & 0 & 0 \\
\hline 8 & 177 & 158 & 8 & 11 & 0 & 0 & 0 & 0 & 123 & 117 & 3 & 3 & 0 & 0 & 0 & 0 \\
\hline 9 & 201 & 182 & 8 & 11 & 0 & 0 & 0 & 0 & 142 & 134 & 4 & 4 & 0 & 0 & 0 & $\mathbf{0}$ \\
\hline 10 & 149 & 141 & 6 & 2 & 1 & 1 & 0 & 0 & 139 & 130 & 9 & 5 & 1 & 1 & 0 & $\mathbf{0}$ \\
\hline 11 & 180 & 168 & 8 & 4 & 0 & 0 & 0 & 0 & 138 & 132 & 3 & 3 & 1 & 1 & 0 & 0 \\
\hline 12 & 214 & 186 & 16 & 12 & 4 & 0 & 2 & 2 & 200 & 172 & 15 & 13 & 2 & 1 & 1 & $\mathbf{0}$ \\
\hline 13 & 273 & 225 & 18 & 30 & 7 & 5 & 0 & 2 & 306 & 266 & 10 & 30 & 4 & 1 & 0 & 3 \\
\hline 14 & 403 & 334 & 22 & 47 & 12 & 6 & 0 & 6 & 390 & 342 & 24 & 24 & 5 & 3 & 2 & 0 \\
\hline 15 & 423 & 337 & 28 & 58 & 26 & 8 & 4 & 14 & 394 & 353 & 27 & 14 & 3 & 3 & 0 & 0 \\
\hline 16 & 395 & 313 & 35 & 47 & 26 & 6 & 8 & 12 & 361 & 314 & 25 & 22 & 4 & 3 & 0 & 1 \\
\hline 17 & 372 & 298 & 26 & 48 & 22 & 4 & 8 & 10 & 326 & 273 & 27 & 26 & 3 & 1 & 0 & 2 \\
\hline 18 & 124 & 115 & 2 & 7 & 1 & 1 & $\mathbf{0}$ & $\mathbf{0}$ & 135 & 104 & 16 & 15 & 0 & 0 & $\mathbf{0}$ & $\mathbf{0}$ \\
\hline \multirow[t]{2}{*}{ Total } & 3558 & 3044 & 209 & 305 & 100 & 32 & 22 & 46 & 3124 & 2775 & 185 & 169 & 23 & 14 & $\mathbf{3}$ & 6 \\
\hline & & $85.6 \%$ & $5.9 \%$ & $8.6 \%$ & $\begin{array}{c}2.8 \% * \\
19.5 \% * *\end{array}$ & $0.9 \%$ & $0.6 \%$ & $1.3 \%$ & & $88.8 \%$ & $5.9 \%$ & $5.4 \%$ & $\begin{array}{l}0.7 \% * \\
6.5 \% * *\end{array}$ & $0.4 \%$ & $0.1 \%$ & $0.2 \%$ \\
\hline
\end{tabular}

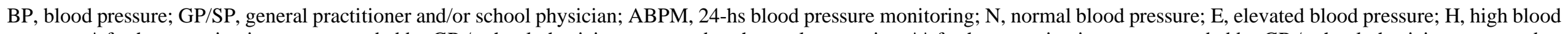

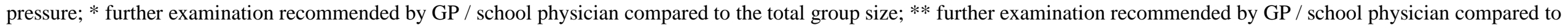
the proposal of our researchers 
Supplementary Table 2B Distribution of blood pressure by sex, age

\begin{tabular}{|c|c|c|c|c|c|c|c|c|c|c|c|c|c|c|c|c|}
\hline & \multicolumn{8}{|c|}{ overweight boys } & \multicolumn{8}{|c|}{ overweight girls } \\
\hline & & \multicolumn{2}{|c|}{$\begin{array}{c}\text { based on first } \\
\text { BP measurement }\end{array}$} & \multirow[b]{2}{*}{$\mathbf{H}$} & \multirow{3}{*}{$\begin{array}{c}\text { further } \\
\text { examination } \\
\text { proposed by GP / } \\
\text { SP }\end{array}$} & \multicolumn{3}{|c|}{ based on ABPM } & \multicolumn{4}{|c|}{$\begin{array}{l}\text { based on first } \\
\text { BP measurement }\end{array}$} & \multirow{3}{*}{$\begin{array}{c}\text { further } \\
\text { examination } \\
\text { proposed by GP } \\
\text { / SP }\end{array}$} & \multicolumn{3}{|c|}{ based on ABPM } \\
\hline & & $\mathbf{N}$ & $\mathbf{E}$ & & & $\mathbf{N}$ & $\mathbf{E}$ & $\mathbf{H}$ & & $\mathbf{N}$ & $\mathbf{E}$ & $\mathbf{H}$ & & $\mathbf{N}$ & $\mathbf{E}$ & $\mathbf{H}$ \\
\hline age (ys) & $\mathbf{n}$ & $<90$ & $90-95$ & $95 \leq$ & & $<90$ & $90-95$ & $95 \leq$ & $\mathbf{n}$ & $<90$ & $90-95$ & $95 \leq$ & & $<90$ & $90-95$ & $95 \leq$ \\
\hline 3 & 10 & 4 & 0 & 6 & 0 & 0 & $\mathbf{0}$ & $\mathbf{0}$ & 6 & 1 & 0 & 5 & 0 & 0 & $\mathbf{0}$ & $\mathbf{0}$ \\
\hline 4 & 12 & 4 & 2 & 6 & 0 & 0 & $\mathbf{0}$ & $\mathbf{0}$ & 12 & 5 & 6 & 1 & 0 & 0 & 0 & 0 \\
\hline 5 & 18 & 6 & 1 & 11 & 0 & 0 & $\mathbf{0}$ & $\mathbf{0}$ & 12 & 6 & 3 & 3 & 0 & 0 & $\mathbf{0}$ & $\mathbf{0}$ \\
\hline 6 & 21 & 11 & 3 & 7 & 0 & 0 & $\mathbf{0}$ & $\mathbf{0}$ & 24 & 18 & 3 & 3 & 0 & 0 & $\mathbf{0}$ & $\mathbf{0}$ \\
\hline 7 & 33 & 14 & 4 & 15 & 2 & 1 & 1 & $\mathbf{0}$ & 17 & 11 & 2 & 4 & 0 & 0 & $\mathbf{0}$ & $\mathbf{0}$ \\
\hline 8 & 30 & 15 & 3 & 12 & 0 & 0 & $\mathbf{0}$ & $\mathbf{0}$ & 23 & 12 & 7 & 4 & 0 & 0 & 0 & 0 \\
\hline 9 & 24 & 9 & 1 & 14 & 2 & 1 & 1 & $\mathbf{0}$ & 35 & 25 & 2 & 8 & 0 & 0 & 0 & 0 \\
\hline 10 & 40 & 15 & 7 & 18 & 8 & 1 & 2 & 5 & 25 & 13 & 2 & 10 & 0 & 0 & 0 & 0 \\
\hline 11 & 55 & 21 & 12 & 22 & 28 & 3 & 14 & 11 & 28 & 17 & 6 & 5 & 2 & 2 & 0 & 0 \\
\hline 12 & 46 & 15 & 14 & 17 & 31 & 0 & 19 & 12 & 43 & 21 & 11 & 11 & 5 & 4 & 0 & 1 \\
\hline 13 & 61 & 26 & 10 & 25 & 35 & 1 & 19 & 15 & 61 & 24 & 20 & 17 & 6 & 3 & 0 & 3 \\
\hline 14 & 104 & 38 & 13 & 53 & 39 & 5 & 22 & 12 & 52 & 24 & 14 & 14 & 4 & 3 & 0 & 1 \\
\hline 15 & 82 & 36 & 19 & 27 & 32 & 1 & 20 & 11 & 58 & 37 & 11 & 10 & 2 & 1 & 0 & 1 \\
\hline 16 & 65 & 28 & 17 & 20 & 29 & 1 & 17 & 11 & 51 & 23 & 18 & 10 & 7 & 4 & 0 & 3 \\
\hline 17 & 54 & 24 & 9 & 21 & 12 & 3 & 2 & 7 & 49 & 23 & 14 & 12 & 5 & 2 & 0 & 3 \\
\hline 18 & 21 & 8 & 5 & 8 & 5 & 3 & 0 & 2 & 10 & 5 & 3 & 2 & 1 & 1 & 0 & 0 \\
\hline \multirow[t]{2}{*}{ Total } & 676 & 274 & 120 & 282 & 223 & 20 & 117 & 86 & 506 & 265 & 122 & 119 & 32 & 20 & 0 & 12 \\
\hline & & $40.5 \%$ & $17.8 \%$ & $41.7 \%$ & $\begin{array}{c}32.9 \% * \\
55.5 \% * *\end{array}$ & $2.9 \%$ & $17.3 \%$ & $12.7 \%$ & & $52.4 \%$ & $24.1 \%$ & $23.5 \%$ & $\begin{array}{c}6.3 \% * \\
13.2 \% * *\end{array}$ & $3.9 \%$ & $0.0 \%$ & $2.4 \%$ \\
\hline
\end{tabular}

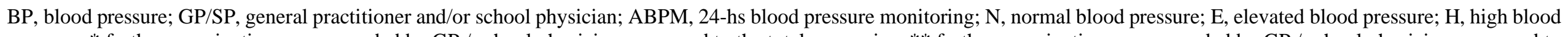

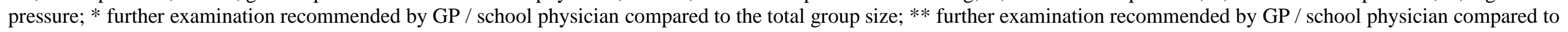
the proposal of our researchers 
Supplementary Table 2C Distribution of blood pressure by sex, age

obese boys

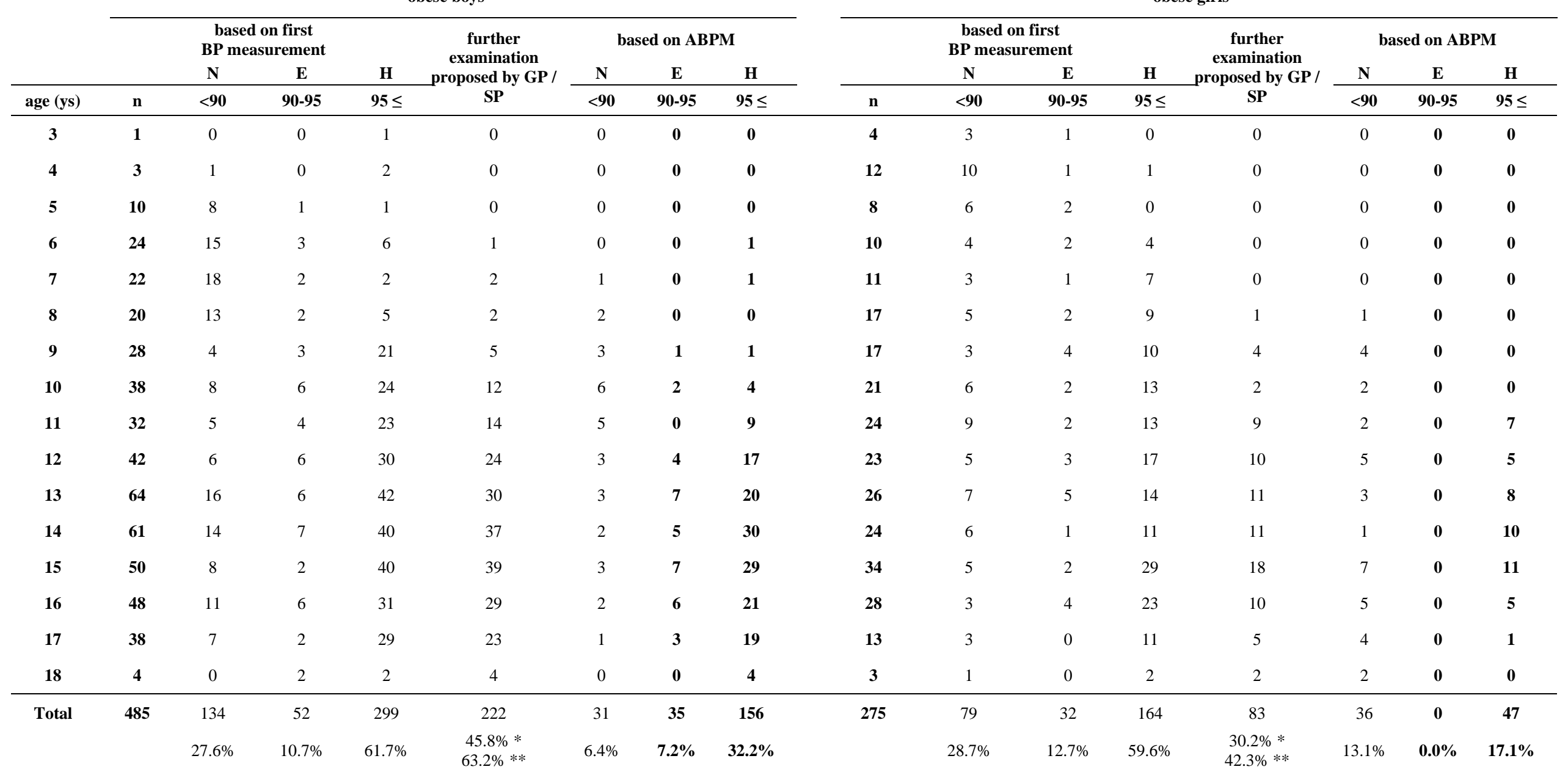

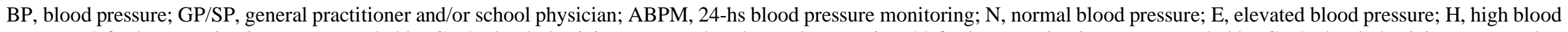

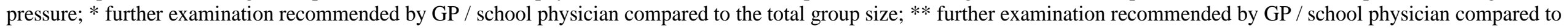
the proposal of our researchers 


\section{ACKNOWLEDGEMENTS}

First, I would like to say thank you to Prof. Dr. Lajos Kemény, DSA the program director of Clinical Medical Sciences Doctoral School to enable me to study in this doctoral program.

I also would like to express my appreciation to my consultant, Dr. Csaba Bereczki, $\mathrm{PhD}$ who always supported and encouraged me during my $\mathrm{PhD}$ studies.

I am thankful to Zoltán Maróti PhD and Tibor Kalmár PhD for their constant help in every aspect of the writing of this thesis and my publications. I am very grateful for their guidance.

I would like to thank Dr. Miklós Illyés, PhD and Prof. Dr. Attila Cziráki, PhD for sharing their knowledge with me.

I wish to thank Gábor Érsek for his help in the field of statistics and data analyzing and I also want to thank dr. Judit Kelemen and Csilla Keresztes, PhD for being the lecturer of my publications.

I am very thankful to my colleagues, friends and family, especially to my mother who helped me all the way with her scientific experience, supported with her enthusiasm, I cannot express my appreciation enough for her investment in this thesis. 